\title{
Diagenesis in tephra-rich sediments from the Lesser Antilles Volcanic Arc: Pore fluid constraints
}

\author{
Manuscript accepted by Geochimica et Cosmochimica Acta
}

\author{
Natalie A. Murray ${ }^{1}$, James McManus ${ }^{1,2,3^{*}}$, Martin R. Palmer ${ }^{4}$, Brian Haley ${ }^{3}$, Hayley \\ Manners ${ }^{4.5}$ \\ ${ }^{1}$ The University of Akron, Department of Geosciences, Akron, OH 44325 \\ ${ }^{2}$ Bigelow Laboratory for Ocean Sciences, 60 Bigelow Dr., East Boothbay, ME \\ ${ }^{3}$ Oregon State University, College of Earth, Ocean, and Atmospheric Sciences, Corvallis, OR \\ 97331 \\ ${ }^{4}$ School of Ocean and Earth Science, University of Southampton, National Oceanography \\ Centre Southampton, Southampton SO14 3ZH, United Kingdom \\ ${ }^{5}$ University of Plymouth, School of Geography, Earth and Environmental Sciences, \\ Plymouth, Devon PL4 8AA, United Kingdom \\ *Corresponding Author: jmcmanus@bigelow.org
}

\begin{abstract}
We present sediment pore fluid and sediment solid phase results obtained during IODP Expedition 340 from seven sites located within the Grenada Basin of the southern Lesser Antilles Volcanic Arc region. These sites are generally characterized as being low in organic carbon content and rich in calcium carbonate and volcanogenic material. In addition
\end{abstract}


to the typical reactions related to organic matter diagenesis, pore fluid chemistry indicates that the diagenetic reactions fall within two broad categories; (1) reactions related to chemical exchange with volcanogenic material and (2) reactions related to carbonate dissolution, precipitation, or recrystallization. For locations dominated by reaction with volcanogenic material, these sites exhibit increases in dissolved Ca with coeval decreases in Mg. We interpret this behavior as being driven by sediment-water exchange reactions from the alteration of volcanic material that is dispersed throughout the sediment package, which likely result in formation of Mg-rich secondary authigenic clays. In contrast to this behavior, sediment sequences that exhibit decreases in Ca, Mg, Mn, and Sr with depth suggest that carbonate precipitation is an active diagenetic process affecting solute distributions. The distributions of pore fluid ${ }^{87} \mathrm{Sr} /{ }^{86} \mathrm{Sr}$ reflect these competitive diagenetic reactions between volcanic material and carbonate, which are inferred by the major cation distributions. From one site where we have solid phase ${ }^{87} \mathrm{Sr} /{ }^{86} \mathrm{Sr}$ (site U1396), the carbonate fraction is found to be generally consistent with the contemporaneous seawater isotope values. However, the ${ }^{87} \mathrm{Sr}$ ${ }^{86} \mathrm{Sr}$ of the non-carbonate fraction ranges from 0.7074 to 0.7052 , and these values likely represent a mixture of local arc volcanic sources and trans-Atlantic eolian sources. Even at this site where there is clear evidence for diagenesis of volcanogenic material, carbonate diagenesis appears to buffer pore fluid ${ }^{87} \mathrm{Sr} /{ }^{86} \mathrm{Sr}$ from the larger changes that might be expected given the high abundance of tephra in these sediments. Part of this carbonate buffering, at this site as well as throughout the region, derives from the fact that the $\mathrm{Sr}$ concentration in the non-carbonate fraction is generally low $(<200 \mathrm{ppm})$, whereas the carbonate fraction has Sr concentrations approaching 1000 ppm.

\subsection{INTRODUCTION}

Explosive volcanism contributes tephra and ash to marine sediments throughout the 
global ocean. For example, it has been estimated that 15 - $20 \mathrm{wt} \%$ of Caribbean Sea sediments are composed of ash (Peters et al. 2000) and, on a larger scale, $\sim 6-60 \mathrm{wt} \%$ of northwest Pacific sediments may be composed of volcanogenic material (Scudder et al. 2009, 2014). Diagenesis of this material can lead to the release of dissolved constituents, precipitation of new minerals (clays and carbonates), and (re)crystallization of various mineral phases (Elderfield et al., 1982; Fisher and Schmincke, 1984; Gieskes et al., 1986; Gieskes et al., 1987; Gieskes et al., 1990a, b, c). In particular, highly reactive glassy particles can exert a strong influence on diagenetic processes (Kutterfolf et al., 2009; Hesse and Schacht, 2011), and these processes can impact the ocean’s elemental budgets (Hart and Staudigel, 1982; Staudigel and Hart, 1982; Aller, 2014). One pertinent example is that these reactions can play an important role in the Earth's carbon cycle by promoting the burial of organic and inorganic carbon, which can ultimately regulate long-term feedbacks between climate and atmospheric $\mathrm{CO}_{2}$ (Haeckel et al., 2001; Wallmann et al., 2008; Hembury et al., 2012).

A large number of Ocean Drilling Program (ODP) and Deep Sea Drilling Project (DSDP) studies have examined the pore fluid geochemistry of deep sea sediments that reflect chemical reaction between pore waters and volcanic material (Gieskes and Lawrence, 1981; Gieskes, 1983; Gieskes et al., 1987; Gieskes et al., 1990a, b, c; Lyons et al., 2000). These sediments often exhibit a characteristic pore fluid relationship whereby decreases in $\mathrm{Mg}$ correspond to increases in Ca (Gieskes and Lawrence, 1981; Giekses, 1983; Gieskes et al., 1987; Gieskes et al., 1990a, b; Lyons et al., 2000). The coeval increases in Ca and depletions in $\mathrm{Mg}$ are thought to reflect the diagenesis of volcanic material, which are often attributed to reaction with basaltic basement, but may also include dispersed volcanic material within the sediment through exchange reactions that occur during secondary clay formation, particularly smectite (Hein et al., 1979; Gieskes et al., 1987; Gieskes et al., 1990a; Chan and Kastner, 
2000; Lyons et al., 2000; Scholtz et al., 2010; Scholtz et al., 2013). The distribution of other elements in pore fluids also show patterns that reflect the alteration of volcanic material, with these alteration products being either a source or a sink of a particular element to the pore fluids (Brumsack and Zuleger, 1992; James and Palmer, 2000; Lyons et al., 2000; Teichert et al., 2005; Scholz et al., 2010; Scholz et al., 2013). Pore fluid changes in Ca, Mg, and Sr can also reflect the precipitation or dissolution of carbonate phases, and in many environments these carbonate reactions dominate the geochemical signatures of diagenesis, regardless of the presence of volcanic matter (Gieskes and Lawrence, 1981; Gieskes, 1983; Gieskes et al., 1990a; Chan and Kastner, 2000; Lyons et al., 2000; Sample et al., 2017). The current study examines diagenetic reactions occurring within the sediment package of tephra-rich sediments, with an emphasis on identifying the conditions under which volcanic material diagenesis will be expressed in the pore fluids.

\subsection{STUDY SITE DETAILS}

The Lesser Antilles volcanic arc is characterized by the westward subduction of the Atlantic plate beneath the Caribbean plate (Macdonald et al., 2000; Picard et al., 2006). The arc extends $800 \mathrm{~km}$ from South America to the Greater Antilles in the north, separating the Caribbean Sea from the Atlantic Ocean (Figure 1) (Macdonald et al., 2000; Le Friant et al., 2003). At $2-4 \mathrm{~cm} \mathrm{y}^{-1}$, convergence of the Atlantic plate and Caribbean plate is slow compared to most active volcanic arcs (Macdonald et al., 2000). To the north of Martinique, the island arc splits into two chains of islands (Figure 1) (Macdonald et al., 2000; Le Friant et al., 2003; Boudon et al., 2013). To the south of Dominica, the two volcanic arcs are superimposed with volcanism occurring from the Oligocene to the present day (Figure 1)

(Germa et al., 2011). To the west of the arc lies the Grenada Basin, formed from the rifting of a back arc (Macdonald et al., 2000). This basin is roughly $150 \mathrm{~km}$ wide and $600 \mathrm{~km}$ long, 
ranging from Saba Bank to the Venezuela margin (Picard et al., 2006). Since the time of back arc rifting, the Grenada Basin has been accumulating sediment, a significant portion of which is provided by the volcanic activity of the arc. Sediment thickness ranges from $7 \mathrm{~km}$ in the north to $12 \mathrm{~km}$ in the south (Macdonald et al., 2000; Picard et al., 2006). Sediments within the basin contain hemipelagic mud, tephra, ash, pumice, volcaniclastic turbidites, and debris flows, with the turbidites and debris flows being a result of flank collapses associated with active volcanoes along the western most arc (Figure 1) (Deplus et al., 2001; Le Friant et al., 2003; Picard et al., 2006; Le Friant et al., 2015; Wall-Palmer et al., 2016).

Sediment cores were collected in 2012 on IODP Expedition 340 to the Lesser Antilles Volcanic Arc (Expedition 340 Scientists, 2012; Le Friant et al., 2013). Three sites were sampled off the coast of Montserrat and five were sampled to the south of Martinique. There are seven cores of interest to this study, the three located in the northern region, U1394 - U1396 and four sites in the southern region (Figure 2). Site descriptions are briefly summarized here from the Expedition 340 reports (Expedition 340 Scientists, 2012; Le Friant et al., 2013; Coussens et al., 2016), which should be consulted for more detailed descriptions. Sites U1394 and U1395 consist of hemipelagic mud, bioclastic, volcaniclastic, and mixed turbidites, volcaniclastics, and tephra whereas Site U1396 is composed of hemipelagic sediment, tephra, and volcaniclastic sand. Site U1396 was located on a bathymetric high and contained less of the coarser volcanic materials observed for the other sites, but nevertheless did have 100 visible layers of tephra as well as cryptotephra (Le Friant et al., 2013; McCanta et al., 2015; Coussens et al., 2016; Palmer et al., 2016). Biostratigraphic analysis notes the abundance of planktic foraminifera through the bioclastic, carbonate-rich deposits (e.g., Wall-Palmer et al., 2014). The southern sites consist of hemipelagic mud containing interbedded tephra, and volcaniclastic turbidites (Expedition 340, 2012; Le Friant et al., 2013). Age constraints at these sites are uncertain; however, the base of Hole U1394B dates 
to $353 \mathrm{ka}$, and the base of Hole U1395B dates to > 1 Ma. A detailed stratigraphic reconstruction of sediments from Site U1396 has been undertaken (Wall-Palmer et al., 2014; Fraass et al., 2016). The uppermost $7 \mathrm{~m}$ of Hole 1396C dates to $\sim 1$ Ma with the base of the core dating to 4.5 Ma (Hatfield, 2015; Coussens et al., 2016). For the southern sites, ages are not well defined.

\subsection{METHODOLOGY}

Most of the data and methods described in this manuscript are available from the IODP data repository or through the various post-cruise data reports (Le Friant et al., 2013; Murray et al., 2016). Nevertheless, for completeness we briefly review the methodology here.

\subsection{Sediment Coring and Sampling}

Sediment cores were collected during Expedition 340 in 2012 using the R/V JOIDES Resolution. An advanced piston corer (APC) and an extended core barrel (XCB) were both employed to retrieve cores during the cruise. The APC and XCB characteristics and system functions can be found in Graber et al. (2002). Briefly, the APC method is used to cut through softer deep-sea sediments and is thought to create minimal sedimentary disturbance relative to other IODP coring systems (Expedition 340 Scientists, 2013). The XCB is necessary for more firm or lithified substrate (Expedition 340 Scientists, 2013). Given the nature of some of the material, including coarse-grained volcanic sands and other debris, there are notable gaps in some of the records presented here. Recovery was typically poorer through course-grained material, or in instances where recovery was successful the material was often not suitable for pore fluid extraction (Expedition 340 Scientists, 2013).

Sampling occurred approximately every 10 meters unless the sediment was unsuitable 
for pore fluid extraction. A 10 - $15 \mathrm{~cm}$ section of whole-round core was removed to begin the squeezing process in the laboratory. Whole-round sections were then processed within a nitrogen-filled bag and then transferred to a hydraulic press for pore fluid extraction (Manheim, 1966). Following the hydraulic press, pore fluids were filtered through $0.45 \mu \mathrm{m}$ filters and subsampled for various dissolved constituents (Expedition 340 Scientists, 2013).

\subsection{Pore Fluid ICP-OES and ICP-MS analysis}

All pore fluid data for this manuscript were presented within data reports associated with the expedition with the exception of the ${ }^{87} \mathrm{Sr} /{ }^{86} \mathrm{Sr}$ (Expedition 340 Scientists, 2013; Le Friant et al., 2013; Murray et al., 2016). The reader is directed to those communications for full data sets and analytical details; however, $\mathrm{Sr}$ and $\mathrm{Sr}$ isotope data for the pore fluids are present in Supplemental Table 1 and for the sediment solid phases in Supplemental Tables 2 and 3. Briefly, pore fluid samples were diluted with 1\% quartz-distilled nitric acid and analyzed by either ICP-MS or ICP-OES. The minor elements were spiked with an artificial seawater mixture to matrix-match samples to approximate seawater concentrations of $\mathrm{Na}, \mathrm{Cl}$, and Mg from ultrapure salts (Sigma Aldrich). The reported uncertainties $(1 \sigma)$ are a combination of the square root of the sum of the squares of the regression uncertainty of the standard curve, calculated from the standard error of regression and the internal uncertainty calculated from the standard deviation of three sample replicates. The analytical detection limit is the point where the measured concentration is $>3 \sigma$ above the analytical zero.

\section{$3.3{ }^{87} \mathrm{Sr} /{ }^{86} \mathrm{Sr}$ analyses}

Pore fluid was processed for Sr isotope analysis using AG-50 and Sr-Spec columns for Sr separation at Oregon State University’s W.M. Keck Collaboratory for plasma mass spectrometry (see Joseph et al., 2013). Mass bias is corrected using ${ }^{86} \mathrm{Sr} /{ }^{88} \mathrm{Sr}$ of 0.1194 , and instrumental offset corrected using ${ }^{87} \mathrm{Sr} /{ }^{86} \mathrm{Sr}$ of 0.710245 (for NBS 987, National Bureau of Standards). The internal reproducibility is \pm 0.000018 for NBS $987(\mathrm{n}=67)$, and our 
external reproducibility is $\pm 0.000024(n=55)$, which is calculated from runs of an in-house standard (EMD ${ }^{\circledR}$ Sr Standard). Solid phase ${ }^{87} \mathrm{Sr} /{ }^{86} \mathrm{Sr}$ ratios were determined either at the University of Southampton or at Oregon State University. For samples analyzed at the University of Southampton, the carbonate fraction was separated by dissolution in $6 \mathrm{M} \mathrm{HCl}$, and the residual samples were dissolved in $\mathrm{HF}-\mathrm{HNO}_{3}$ for $24 \mathrm{~h}$ on a hot plate at $130{ }^{\circ} \mathrm{C}$. The solution was then evaporated until dry and redissolved in $3 \mathrm{M} \mathrm{HNO}_{3}$. The $\mathrm{Sr}$ was isolated using Sr resin (Eichrom Industries, Illinois, USA) and the Sr isotope ratios measured on a VG Sector 54 mass spectrometer. Reported values are the average of 150 ratios obtained by measuring ion intensities in multi-dynamic collection mode normalized to ${ }^{86} \mathrm{Sr} /{ }^{88} \mathrm{Sr}=0.1194$. Measured vales of NBS SRM-987 were ${ }^{87} \mathrm{Sr} /{ }^{86} \mathrm{Sr}=0.710297 \pm 0.000029(2 \mathrm{SD}, \mathrm{n}=24)$ during the measurement period, with the Sr isotopic data normalized to NBS SRM-987 = 0.710248. Total solid phase ${ }^{87} \mathrm{Sr} /{ }^{86} \mathrm{Sr}$ ratios were determined on a number of samples at Oregon State University (Supplemental Table 3) following the general approach outlined above for the pore fluids. These samples were digested as described in Muratli et al. (2010 and 2012) and the ancillary data for these digests are available in Murray et al. (2016).

\subsection{RESULTS}

\subsection{Pore fluids}

Generally, Site U1394 exhibits larger pore fluid chemical gradients as compared to U1395 (Figures 3 and 4). $\mathrm{NH}_{4}$ concentrations reach values as high as $2 \mathrm{mM}$, alkalinity in excess of $5 \mathrm{mM}$, and sulfate concentrations that decline to as low as $\sim 10 \mathrm{mM}$ at site U1394 whereas U1395 is similar but with higher sulfate concentrations (Figures 3A,B and 4A,B). Dissolved Mn concentrations typically range between $\sim 1$ and $2 \mu \mathrm{M}$ at depth, with slightly elevated concentrations near the surface. At both sites, Ca and Mg concentrations decrease below their seawater values (Figures 3 and 4C). At depth, pore fluid Ca concentrations increase whereas Mg concentrations are depleted at depth at both sites. Pore fluids are 
generally enriched in $\mathrm{Si}, \mathrm{Li}$, and $\mathrm{Sr}$ relative to their seawater values and depleted in $\mathrm{K}$ (Figures 3 and 4D, E). ${ }^{87} \mathrm{Sr} /{ }^{86} \mathrm{Sr}$ values for site U1395 decrease slightly with depth, with most of the change in ${ }^{87} \mathrm{Sr} /{ }^{86} \mathrm{Sr}$ occurring between $\sim 10$ and 50 meters below the sediment surface. The structure of the dissolved ion pore fluid profiles differs significantly near the bottom of the profiles, in particular for Site U1394 there are larger near-bottom gradients for a number of constituents as compared to U1395.

Pore water data for site U1396 are distinct from the other pore fluid profiles from this study (Figure 5A-E), with the low $\mathrm{NH}_{4}$ and high sulfate concentrations indicating that diagenetic conditions were less reducing than at the other northern sites, although dissolved Mn increases with depth throughout the sequence. Alkalinity is depleted relative to its seawater value and Ca increases by roughly a factor of three within the upper 20 meters of the sequence. The Mg depletion mirrors the Ca enrichment. As with U1394 and U1395, ${ }^{87} \mathrm{Sr}$ ${ }^{86} \mathrm{Sr}$ values decrease with depth, but U1396 achieves significantly lower ${ }^{87} \mathrm{Sr} /{ }^{86} \mathrm{Sr}$ values ( 0.7083) in the pore waters than at the other sites discussed here. Similar to the other northern sites, generally $\mathrm{Li}$ and $\mathrm{Si}$ are enriched over their seawater values whereas $\mathrm{K}$ is depleted.

The southern sites exhibit similarities to the sites from the north, with the more offshore Sites U1398 and U1399 having larger enrichments in $\mathrm{NH}_{4}$ and alkalinity and larger depletions in sulfate as compared to U1397 and U1400 (Figures 6 - 9). At U1398 and 1399 Ca, Mg, Sr, and ${ }^{87} \mathrm{Sr} /{ }^{86} \mathrm{Sr}$ all decrease with depth, with the exception of the deepest data point from U1398, which shows an enrichment in Ca and Sr. Silica increases and Li generally remains near its seawater value with some slight concentration enrichment at the surface and near the base of the core. At U1400, Ca, Mg, and Sr remain close to present day seawater values with a notable increase in $\mathrm{Ca}$, $\mathrm{Sr}$, and $\mathrm{Li}$ near the base of the core and a decrease in $\mathrm{Mg}$ and a change in the ${ }^{87} \mathrm{Sr} /{ }^{86} \mathrm{Sr}$ gradient toward lower values (Figure 9). One additional point 
of note regarding U1400 is that the core sampled much deeper within the sediment column as compared to the other sites presented here. The behavior of $\mathrm{K}$ throughout the sites is characterized by depletions at all of the sites, with the magnitude of those depletions varying considerably.

\subsection{Solid phases}

\subsection{1 ${ }^{87} \mathrm{Sr} /{ }^{86} \mathrm{Sr}$ in Sediments from U1396}

${ }^{87} \mathrm{Sr} /{ }^{86} \mathrm{Sr}$ in the carbonate fraction from Site U1396 has values close to those of contemporaneous seawater (Figure 10), which have increased over time (e.g., Elderfield, 1986; Paytan et al., 1993). The average Sr concentration in this fraction is $775 \mathrm{ppm}$ (Supplemental Table 2). For the de-carbonated (residual) sedimentary fraction, which has an average Sr concentration of $\sim 135 \mathrm{ppm},{ }^{87} \mathrm{Sr} /{ }^{86} \mathrm{Sr}$ values range between $\sim 0.7074$ and 0.705 . The pore fluid ${ }^{87} \mathrm{Sr} /{ }^{86} \mathrm{Sr}$ has the lowest values of the sites presented here and these values are between those of the carbonate and the non-carbonate fraction, with the average being lower than the carbonate values.

We include the bulk solid phase ${ }^{87} \mathrm{Sr} /{ }^{86} \mathrm{Sr}$ values from the other sites for comparison (Table S3). Because these values are total digests, they represent a mixture of phases and Sr isotope values and the values are difficult to interpret in terms of diagenetic processes. Nevertheless these Sr isotope values are all between the carbonate values and the residual values for site U1396.

\subsection{Discussion}

\subsection{Diagenetic processes involving volcanic material}

Pore fluid chemistry indicates that the diagenetic reactions fall into two broad categories; (1) reactions related to exchange with volcanogenic matter, and (2) reactions related to carbonate dissolution, precipitation, and/or recrystallization. Reactions within these 
categories are to be expected because regional sedimentation is dominated by these combined inputs (e.g., Gieskes and Lawrence, 1981; Gieskes et al., 1990a, b, c; Lyons et al., 2000; Le Friant 2013, 2015; Palmer et al., 2016).

The reactions between the pore fluids and volcanogenic material are most clear at sites U1395 and U1396 in the north and below 300 m at U1400 in the south. Signatures of these reactions are most strongly observed for the dissolved major elements, Ca and Mg. At site U1395, there is an initial decrease in Ca concentration with sediment depth followed by an increase below 20 meters (Figure 4). Below this depth, increases in dissolved Ca generally mirror the decreases in dissolved Mg (Figures 4, 11). At site U1396 there is a shift in pore water $\mathrm{Ca}$ and $\mathrm{Mg}$ concentrations near the sediment surface with a 1:1 offset from their respective seawater values (Figure 5, 11). At Site U1400, the increase in Ca with accompanying decrease in $\mathrm{Mg}$ appears to be limited to the deeper ( > $300 \mathrm{~m}$ ) portions of the sediment column (Figure 9, 11B). Similar inverse relationships between Ca and Mg have been noted in other studies and have been attributed to a variety of processes including $\mathrm{CaCO}_{3}$ dissolution, volcanic glass alteration, diagenesis of carbonate and silicate sediments, and/or alteration of underlying basaltic crust (e.g., Gieskes and Lawrence, 1981; Gieskes, 1983; Gieskes et al., 1987; Gieskes et al., 1990a; Lyons et al., 2000). The most likely interpretation of the inverse Ca-Mg relationship at the sites presented here is exchange reactions associated with authigenic smectite formation (Hein et al., 1979; Gieskes and Lawrence, 1981; Gieskes, 1983; Gieskes et al., 1987; Martin et al., 1996; James and Palmer, 2000; Lyons et al., 2000; Scholz et al., 2013). These exchange reactions arise because volcanic ash and tephra from subduction zone volcanism contain reactive mafic to intermediate minerals: including, olivine $\left[\left(\mathrm{Mg}, \mathrm{Fe}^{2+}\right)_{2} \mathrm{SiO}_{4}\right]$, pyroxene $\left[\left(\mathrm{Ca}, \mathrm{Mg}, \mathrm{Fe}^{2+}\right)_{2} \mathrm{Si}_{2} \mathrm{O}_{6}\right]$, amphibole [( $\left.\mathrm{Mg}, \mathrm{Fe}^{2+}\right)_{7} \mathrm{Si}_{8} \mathrm{O}_{22}(\mathrm{OH})_{2}$ ], and Ca-rich plagioclase [Ca, $\mathrm{Al}_{2}, \mathrm{Si}_{2} \mathrm{O}_{8}$ ] (Gilkes and McKenzie, 1988). For example, in cores from DSDP Legs 35 and 38, where increases in Ca 
accompany decreases in $\mathrm{Mg}$, the dissolution of plagioclase and volcanic glass is thought to release Ca as Mg is removed from pore fluids to form Mg-smectite (Kastner and Gieskes, 1976; Gieskes et al., 1987). The involvement of smectite in these reactions is also evidenced by its high cation exchange potential and its prevalence in convergent margin settings with volcanic input (Griffin et al., 1968; Gieskes et al., 1987; Scholz et al., 2010).

The sites in the Lesser Antilles where pore fluid Ca and Mg concentrations appear to be driven by alteration of volcanic matter (U1395, U1396, U1400) do not show changes that are as large as some of those observed during ODP Leg 110 in the eastern Caribbean (e.g., Gieskes et al., 1990b) or ODP Leg 165 in the western Caribbean (Lyons et al., 2000), where the $\Delta \mathrm{Ca}: \Delta \mathrm{Mg}$ shows a range of 0.1 to 4 (Figure 11A, C). Data from Leg 110 (site 671), which sampled sediment east of the volcanic arc from the northern Barbados accretionary complex, shows similar $\Delta \mathrm{Ca}: \Delta \mathrm{Mg}$ in the shallower reaches of the sediment package to those observed at sites U1395 and U1396, followed by a trend that is similar to the larger $\Delta \mathrm{Ca}: \Delta \mathrm{Mg}$ changes seen at site 1001 (Figure 11C, Gieskes et al., 1990a, b, c). The larger Ca:Mg ratios from cores from both ODP Legs 110 and 165 are thought to be partially a result of alteration of the underlying basaltic basement (Gieskes et al., 1990a, b, c; Lyons et al., 2000), a process that can strongly enrich deep sediment fluids in Ca, which can then lead to deep authigenic carbonate precipitation (e.g., Torres et al., 2015; Sample et al., 2017). The lack of these larger Ca:Mg ratios in the Grenada Basin suggest that $\Delta \mathrm{Ca}: \Delta \mathrm{Mg}$ at $\mathrm{U} 1395$ and U1396 are dominated by alteration of volcanic matter dispersed throughout the sediment column. The $\Delta \mathrm{Ca}: \Delta \mathrm{Mg}$ pattern at site 671 , as well as other sites from Leg 110 , shows a transition between a ratio of $\sim 1$ to $\sim 4$ in sediments from the accretionary complex (Figure 11C, Gieskes et al., 1990a), and is likely driven by fluid reaction within the accretionary prism where tectonics are forcing changes in the hydrology and chemistry of fluid migration (e.g., Gieskes et al., 1990b; Blanc et al., 1991; Vrolijk et al., 1991). 
Pore water Si, K, and Li distributions could be interpreted to support the hypothesis that alteration of volcanic material is an important reaction in these sediments with $\mathrm{Si}$ and $\mathrm{Li}$ generally increasing whereas K generally decreases (Sigurdsson et al., 1997; Chan and Kastner, 2000; James and Palmer, 2000). Although we recognize that the increases in Si and Li with increasing depth can be attributed to continued alteration of volcanic ash throughout the sediment package (Lyons et al., 2000), these constituents are also influenced by a number of other sedimentary reactions that likely mask specific processes related to tephra diagenesis. For example, Si is also produced in the pore fluids during biogenic silica dissolution and $\mathrm{Si}$ and $\mathrm{Li}$ are both taken up during authigenic clay formation independent of volcanic material diagenesis (e.g., Aller, 2014). Furthermore, the slightly elevated Li concentration, which is pervasive throughout the sediment column of some of the sites, particularly those rich in $\mathrm{NH}_{4}{ }^{+}$, could be driven by $\mathrm{NH}_{4}{ }^{+}$substitution for $\mathrm{Li}$ in clay mineral inter-layer exchange sites (e.g., Gieskes, 1983). The decrease in K in nearly all cores is a commonly observed characteristic of that dissolved constituent and is likely driven by authigenic clay formation although alteration of basalt is certainly a possible mechanism for its depletion as well (e.g., Sun et al., 2016). The notable differences between the vertical distributions of $\mathrm{Si}, \mathrm{Li}$, and $\mathrm{K}$ as compared to $\mathrm{Ca}, \mathrm{Mg}$, and $\mathrm{Sr}$ suggest that these former constituents are likely to be influenced by other, perhaps more gradual, authigenic chemical changes within the sedimentary package, e.g., biogenic opal dissolution and authigenic precipitation reactions, as compared to $\mathrm{Ca}, \mathrm{Mg}$, and $\mathrm{Sr}$, which exhibit more abrupt distribution changes, and which we interpret as being related to direct interactions with fresh volcanic material (e.g., U1396).

The ${ }^{87} \mathrm{Sr} /{ }^{86} \mathrm{Sr}$ pore fluid data likely reflect a confluence of processes including carbonate precipitation and dissolution as well as reactions with tephra (Figure 12). The gray box in this figure denotes the approximate ${ }^{87} \mathrm{Sr} /{ }^{86} \mathrm{Sr}$ value of seawater over the past $\sim 4$ 
Ma and highlights the range in Sr concentration in the upper sediment package, with an accompanying relatively small change in ${ }^{87} \mathrm{Sr} /{ }^{86} \mathrm{Sr}$ with the exception of Sites U1396, U1398, and to a lesser extent U1400. As one example, Site U1395 exhibits a large increase in pore water Sr concentrations, but is accompanied by a relatively small variation in the ${ }^{87} \mathrm{Sr} /{ }^{86} \mathrm{Sr}$ value of the pore fluids (Figure 12). We hypothesize that this pattern of Sr isotope systematics is likely driven by carbonate recrystallization reactions (e.g., Baker et al., 1982). These reactions have the net effect of adding $\mathrm{Sr}$ to pore fluid, and because the carbonate $\mathrm{Sr}$ isotope values are those of contemporaneous seawater, these reactions "buffer" the pore fluid Sr isotope values toward more radiogenic values (e.g., Richter and DePaolo, 1988; Fantle and DePaolo, 2006). Although the magnitude of the ${ }^{87} \mathrm{Sr} /{ }^{86} \mathrm{Sr}$ changes seem somewhat small at most of our sites relative to U1396, they are also small relative to those samples on Leg 110 (Gieskes et al., 1990a). However, many of those samples were taken from much deeper (older) within the sediment column and may have experienced greater reaction with the basalt or volcanic ash.

The upper portion of Site U1396 shows the greatest perturbations to the dissolved Ca, $\mathrm{Mg}$, and alkalinity pore water concentrations, the maximum pore water Sr concentration as well as the largest change in ${ }^{87} \mathrm{Sr} /{ }^{86} \mathrm{Sr}$ ratios (Figures 5, 12). This site is the only site where we have ${ }^{87} \mathrm{Sr} /{ }^{86} \mathrm{Sr}$ data from both the carbonate and non-carbonate fraction of the sediments (Figure 10). The ${ }^{87} \mathrm{Sr} /{ }^{86} \mathrm{Sr}$ of the carbonate fraction from Site U1396 is generally consistent with what would be expected from the contemporaneous seawater isotope value (dashed line in Figure 10), with small deviations to lower values near the top of the core. These variations could be related to diagenetic exchange between the carbonate and non-carbonate material (Figure 10) or potentially are an artifact of leaching of fresh, non-carbonate material. The non-carbonate fraction has lower ${ }^{87} \mathrm{Sr} /{ }^{86} \mathrm{Sr}$ values, which range from 0.707372 to 0.705178 (Supplemental Table 2). This fraction likely represents a mixture of the 
regional volcanogenic signature, the more distal atmospheric dust signature, as well as any diagenetic overprinting (clay formation) by more radiogenic seawater Sr isotope values. Indeed for the other sites the bulk sediment ${ }^{87} \mathrm{Sr} /{ }^{86} \mathrm{Sr}$ values are generally between the carbonate and non-carbonate values (Supplemental Table 3) although we do note here the somewhat surprisingly high Sr concentrations at Site U1395 even though the ${ }^{87} \mathrm{Sr} /{ }^{86} \mathrm{Sr}$ values bracket the range of values noted here (Murray et al., 2016). The Sr isotope values of the pore waters at Site U1396 have the lowest ${ }^{87} \mathrm{Sr} /{ }^{86} \mathrm{Sr}$ values of any of the cores and we infer that this site is the most impacted by reaction with volcanogenic material. This impact is noteworthy in that the Sr pore fluid concentration values change significantly within the upper portion of the sediment package despite the presence of a large carbonate $\mathrm{Sr}$ reservoir (e.g., $500-1000$ ppm Sr). The high concentration of Sr in the carbonate fraction contrasts with the much lower Sr concentrations in the residual material ( 100 - $200 \mathrm{ppm})$, and this residual material will presumably include a volcanic ash fraction that has particularly low ${ }^{87} \mathrm{Sr} /{ }^{86} \mathrm{Sr}$ values (e.g., Gieskes et al., 1990a, b, c). In the deeper sections at this site, between 3 and $4 \mathrm{Ma}$, there is a significant shift in the ${ }^{87} \mathrm{Sr} /{ }^{86} \mathrm{Sr}$ values of the non-carbonate sediment fraction indicating a change in the source of this material. These lower values are consistent with volcanic rocks derived from the Lesser Antilles (0.7039 - 0.7058, Hawkesworth et al., 1979). Neither the pore fluid nor the carbonate values are impacted by this isotopic shift (Figure 10), which implies that alteration of the volcanogenic phase is not the primary determinant of the pore fluid composition at this depth, rather the deeper pore fluid ${ }^{87} \mathrm{Sr} /{ }^{86} \mathrm{Sr}$ values are likely being dominated by the higher Sr reservoir within the carbonate matrix (e.g., Fantle and DePaolo, 2006).

For the southern sites, pore water Sr concentrations at Site U1400 are nearly constant throughout the sediment package at a concentration closer to its seawater value as compared to Site U1396 (Figure 9), and only the deeper samples have ${ }^{87} \mathrm{Sr} /{ }^{86} \mathrm{Sr}$ pore fluid values 
which, coupled with the changes in Ca and Mg suggest a significant contribution from a less radiogenic (volcanic) substrate. The ${ }^{87} \mathrm{Sr} /{ }^{86} \mathrm{Sr}$ for this site is also likely being heavily influenced by the large carbonate reservoir via carbonate dissolution and recrystallization processes. It is important to note that there is not a well-defined age model for this core, which makes it impossible to assess the magnitude of the contemporary seawater contribution to dissolved Sr. Site U1398 has a significantly different pattern compared to the other cores with a signature of Sr removal in the upper sediment column followed by an increase in Sr with less radiogenic ${ }^{87} \mathrm{Sr} /{ }^{86} \mathrm{Sr}$ values (Figure 12). We suggest that this pattern implies that carbonate precipitation or perhaps other authigenic mineral formation is removing some of the Sr, but that reactions with volcanic material that add Sr (as well as $\mathrm{Ca}$ ) to the pore fluid can overcome this process deeper in the sediment column. This point is discussed further below in the context of carbonate diagenesis.

\subsection{Precipitation and Recrystallization of Carbonate Phases}

As mentioned above, carbonate precipitation likely occurs throughout the sedimentary package within the Grenada Basin, but the evidence for this process is particularly strong at Sites U1394 (upper 100 meters) and U1399. Calculations of calcite saturation state in these types of sediments are equivocal as accurate estimates for $\mathrm{pH}$ and even for the concentration of alkalinity are difficult to obtain. This difficulty is partly caused by depressurization and degassing artifacts during core and sample recovery. Nevertheless here we utilize saturation state calculations from $\mathrm{CO}_{2}$ calc (version 1.2.1, M. Hansen, L. Robbins, J. Kleypas, S. Meylan) for estimating aragonite and calcite saturation in the fluids from sites U1394, U1398, and U1399. These calculations suggest that for these sites, the pore fluids are generally supersaturated with respect to calcite (Figure 13); however, as noted the uncertainties in the carbonate parameters are potentially large and an offset of $+0.2 \mathrm{pH}$ units could lead to an overestimate of $\Omega$ on the order of 1 unit, which, given the limited range in $\Omega$, 
is significant. In the case of site U1394 (upper 100 meters) the three carbonate-forming cations (Ca, Mg, Mn) also decrease with depth, whereas for Site U1399, four of the divalent cations decrease with depth (Ca, Mg, Mn, Sr). The weaker correlation between Ca and Mg at $\mathrm{U} 1394\left(\mathrm{r}^{2}=0.38\right)$ as compared to $\mathrm{U} 1399\left(\mathrm{r}^{2}=0.75\right)$ stems from the fact that in the lower 100 meters of U1394, Ca and Mg concentrations suggest that there is a switch in the primary diagenetic mechanism from carbonate precipitation to alteration of volcanic matter and/or dissolution of carbonate phases (Figures 11A, B). The cation results from site U1398 are somewhat different from the other sites and we relate this to the competition between carbonate precipitation reactions and reactions that involve tephra diagenesis (Figure 11A, B). The competing impact from tephra diagenesis, which will enrich the fluids in Ca and (perhaps) Sr, is most notable in the deeper section of this core where $\mathrm{Sr}$ and Ca begin to increase with depth as ${ }^{87} \mathrm{Sr} /{ }^{86} \mathrm{Sr}$ values decline (Figure 7, 11). Taken together the calculations and the covariance of $\mathrm{Ca}$ and $\mathrm{Mg}$, in particular, with the increases in fluid alkalinity support the notion that these cores are likely undergoing carbonate precipitation reactions. Furthermore, all three of these sites exhibit distinctly different behaviors in their dissolved Ca and Mg profiles compared to sites U1395, U1396, and U1400 (Figures 11A, B).

Precipitation of authigenic carbonates can occur under a variety of diagenetic conditions from oxic to anoxic and from the pelagic ocean to the coastal ocean (Hein et al., 1979; Sigurdsson et al., 1997; Lyons et al., 2000; Hesse and Schacht, 2011; Joseph et al., 2012; Aller, 2014; Sample et al., 2017), but the precipitation of Ca-Mg carbonates is favored under sulfate reducing environments (Warthman et al., 2000; Hesse and Schacht, 2011; Aller 2014; Sample et al., 2017). At sites U1394, U1398, and U1399, sulfate reduction is occurring (Figures 3, 7, 8), which increases the alkalinity needed for carbonate precipitation (Hein et al., 1979; Sigurdsson et al., 1997; Lyons et al., 2000; Hesse and Schacht, 2011; Joseph et al., 
2012; Aller, 2014). Although dolomite precipitation is normally inhibited in anoxic, low temperature settings, laboratory studies suggest the possibility of dolomite precipitation (Warthman et al., 2000) as well as Mg-calcite precipitation (Van Lith et al., 2003) in the presence of sulfate reducing bacteria, which provides a mechanism for raising alkalinity and $\mathrm{pH}$ for formation of these carbonate phases. However, dolomite was not found in any of the samples examined during this study and it is indeed unlikely that this phase would be precipitating in these sediments (Murray, 2016). Nevertheless XRD results from select samples from the sulfate reducing sections revealed that Mg-calcite is an important carbonate phase accumulating in U1394 and in several samples from U1399 (Expedition 340 Scientists, 2013; Murray, 2016). These results are not surprising, however, as the presence of Mg-rich carbonate within the sediments is likely to be dominated by depositional processes, rather than authigenic processes. Indeed, we can demonstrate that the accumulation of Ca from authigenic processes will be dwarfed by the sediment depositional processes by considering a comparison between the rate of Ca uptake from pore fluids to the accumulation of $\mathrm{Ca}$ as primary carbonate. This calculation is based on a dissolved Ca concentration gradient from Site U1399 (0.13 mmol L-1 $\left.\mathrm{m}^{-1}\right)$, a porosity of 0.5 and the diffusion coefficient formulation from Sun et al. (2016), yielding a flux of $4 \times 10^{-5} \mathrm{mmol} \mathrm{cm}^{-2} \mathrm{y}^{-1}$. We assume a typical carbonate concentration of $20 \%$, a sediment density of $2 \mathrm{~g} \mathrm{~cm}^{-3}$, and a sedimentation rate of $0.05 \mathrm{~cm} \mathrm{y}^{-1}$, which is based on the sedimentation rate at site U1395. These assumptions yield a Ca accumulation rate of $0.2 \mathrm{mmol} \mathrm{cm}^{-2} \mathrm{y}^{-1}$. These calculations are crude at best, but it is difficult to envision a three to four order of magnitude change in these assumptions that would bring the rates of carbonate accumulation and authigenic precipitation values closer. Even though both the accumulation of $\mathrm{Ca}$ and $\mathrm{Mg}$ are driven by delivery rather than authigenic processes, the $\Delta \mathrm{Ca}: \Delta \mathrm{Mg}$ ratio, particularly in U1398 and U1399 does point to uptake by a Mg-rich authigenic carbonate phase, i.e., the net $\Delta \mathrm{Ca}: \Delta \mathrm{Mg}$ ratio is $\sim 1$, 
particularly in U1398 and U1399 (Figure 11). In summary, and as can be seen in the data shown in Figures 11A \& B, there are effectively two sinks for Mg within these sediments, volcanic material alteration, which leads to a 1:1 exchange in Ca, and Mg-rich carbonate precipitation, which leads to uptake of both constituents.

In environments rich in mud and tephra/pumice, other elements are known to compete for sites within the authigenic carbonate structure as well (Hein et al., 1979; Mucci, 1987). At Site U1394 decreases in Ca and Mg also coincide with decreases in dissolved Mn above 100 meters (Figures 3, 14A) and at Site U1399 $\left(r^{2}=0.84\right)$ the decrease occurs below $\sim 40$ meters (Figures 6, 14B). Rhodochrosite $\left(\mathrm{MnCO}_{3}\right)$ precipitation is one possible explanation for the close coupling between Ca and Mn (Hein et al., 1979; Mucci, 1987). Rhodochrosite can precipitate as coatings on pre-existing carbonate debris or as fine crystals dispersed within the sediment package (Hesse and Schacht, 2011). Although dissolved Mn correlates with Ca at both sites, rhodochrosite was not detected (Murray, 2016); however, it is likely that if this phase is present, it is an undetectable component of the sediment package. For example, using a similar approach for the calculations above for Ca in U1399, and assuming a change in dissolved Mn of $1 \mu \mathrm{M}$ meter $^{-1}$ (Figure 8) we would expect a sediment concentration of $\sim 0.1 \mu \mathrm{g} \mathrm{Mn} \mathrm{g}_{\text {sed }}{ }^{-1}$, which is unlikely to be seen in the bulk XRD approach used by Murray (2016).

Although the coincident decrease in Sr and Ca at U1399 Ca $\left(r^{2}=0.94\right)$ (Figure 14B). may be attributed to the precipitation of aragonite with depth (Irwin, 1980; Lyons et al., 2000; Tang et al., 2008), we consider this possibility to be unlikely. In terms of aragonite saturation, for a sample with a $\mathrm{pH}$ of 7.4 and an alkalinity of $5.9 \mathrm{mM}, \Omega_{\text {arag }}=0.8$, whereas for a $\mathrm{pH}$ of 7.6 and an alkalinity of $10.6 \mathrm{mM}, \Omega_{\text {arag }}=1.3$. Although these values are representative of those seen at site U1399 and could imply marginally favorable conditions for aragonite precipitation, we view these saturation values to be overestimates given the uncertainty of the 
$\mathrm{pH}$ values as discussed above (i.e., the $\mathrm{pH}$ values are likely to be artificially high). We thus consider the authigenic precipitation of aragonite to be unlikely and suggest that the depletions in Sr are most likely caused by the incorporation into calcite or some other Sr-rich phase rather than aragonite (Murray, 2016). The notion that Sr is associated with reprecipitation of a carbonate phase should be taken with caution as recrystallization of calcium carbonate typically results in partitioning of Sr into pore fluid rather than precipitation into the carbonate phase (Baker et al., 1982). This point may imply that the coincidence between the Sr and Ca at U1399 is simply fortuitous and that $\mathrm{Sr}$ uptake is being driven by other non-carbonate diagenetic phases or minerals (Elderfield et al., 1982; Gieskes et al., 1986).

\subsection{Conclusions}

The sediments from the Grenada Basin indicate that sediment diagenesis is governed by solute release and precipitation reactions that are driven by the presence of tephra as well as by reactions involving carbonate. At sites U1395, U1396, and U1400, increases in Ca mirror decreases in Mg, likely reflecting alteration of volcanic matter dispersed within the sediment column to form authigenic smectite. In contrast, Sites U1394 and U1399 show coincident decreases in dissolved Ca, Mg, Mn, and in the case of U1399 Sr as well, likely reflecting a dominance of carbonate precipitation, specifically a Mg-rich calcite, which is occurring under the sulfate reducing conditions prevalent throughout much of the region. The

${ }^{87} \mathrm{Sr} /{ }^{86} \mathrm{Sr}$ data presented here support the conclusions based on the major cation data. In particular, site U1396 has the most diagnostic data reflecting pore fluid tephra diagenesis in the upper meters of the sediment column (high Ca, low Mg, low ${ }^{87} \mathrm{Sr} /{ }^{86} \mathrm{Sr}$ ). 


\section{Acknowledgements}

This manuscript used samples provided by the Integrated Ocean Drilling Program (IODP) from Expedition 340. IODP is sponsored by the U.S. National Science Foundation (NSF). The authors are indebted to all the participants of Expedition 340 for their contributions during the expedition in particular we appreciate the efforts of the co-chief scientists A. Le Friant and O. Ishizuka. Appreciation is extended to Jesse Muratli at Oregon State University for his work in the laboratory. Financial support was provided by the U.S. Science Support Program (USSSP) and the US National Science Foundation under grant Numbers 1360077 and 1715106 for shore-based analyses. MRP acknowledges NERC grant NE/K00543X/1 for financial support. We are also indebted to Joris Gieskes and one anonymous reviewer for their thoughtful contributions to this manuscript. 


\section{References}

Aller, R. (2014) Sedimentary diagenesis, depositional environments, and benthic fluxes. Treatise on Geochemistry. v. 8, p. 293-334.

Baker, P.A., Gieskes, J.M., Elderfield, H. (1982) Diagenesis of carbonates in deep-sea sediments—Evidence from Sr/Ca ratios and interstitial dissolved Sr data, J. Sed. Pet., 52, 0071-0082.

Blanc, G., Boulegue, J. and Gieskes, J.M. (1991). Chemical evidence for advection of fluid in the sedimentary series of the Barbados accretionary complex (Leg 110). Oceanologica Acta, 1991: 33-49

Boudon, G. Villemant, B. Le Friant, A. Paterne, M. and Cortijo, E. (2013) Role of large flank-collapse events on magma evolution of volcanoes. Insights from the Lesser Antilles Arc. Journal of Volcanology and Geothermal Research, 263, p. 224-237.

Brumsack, H. and Zuleger, E. (1992) Boron and boron isotopes in pore waters from ODP Leg 127, Sea of Japan. Earth and Planetary Science Letters, 113, 427-433.

Chan, L. and Kastner, M. (2000) Lithium isotopic compositions of pore fluids and sediments in the Costa Rica subduction zone: implications for fluid processes and sediment contribution to the arc volcanoes. Earth and Planetary Science Letters, 183, 275-290.

Coussens, M.F. Wall-Palmer, D. Talling, P.J. Watt, S.F.L. Hatter, S.J. Cassidy, M. Clare, M. Jutzeler, M. Hatfield, R. McCanta, M. Kataoka, K.S. Endo, D. Palmer, M.R. Stinton, A. Fujinawa, A. Boudon, G. Le Friant, A. Ishizuka, O. Gernon, T. Adachi, T. Aljahdali, M. Breitkreuz, C. Frass, A.J. Hornbach, M.J. Lebas, E. Lafuerza, S. Maeno, F. Manga, M. Martinez-Colon, M. McManus, J. Morgan, S. Saito, T. Slagle, A. Subramanyam, K.S.V. Tamura, Y. Trofimovs, J. Villemant, B. Wang, F. and the Expedition 340 Scientists (2015) Synthesis: stratigraphy and age control for IODP Sites U1394, U1395, and U1396 offshore Montserrat in the Lesser Antilles. In Le 
Friant, A., Ishizuka, O., Stroncik, N.A., and the Expedition 340 Scientists, Proc. IODP, 340: Tokyo (Integrated Ocean Drilling Program Management International, Inc.), , 340, 1-19. doi:10.2204/iodp.proc.340.204.2016

Deplus, C. Le Friant, A. Boudon, G. Komorowski, J. Villemant, B. Harford, C. Ségoufin, J. and Cheminée, J. (2001) Submarine evidence for large-scale debris avalanches in the Lesser Antilles Arc. Earth and Planetary Science Letters, 192, p. 145-157.

Elderfield, H. (1986) Strontium isotope stratigraphy. Palaeogeography, Palaeoclimatology, Palaeoecology, 57: 71-90.

Elderfield, H. and Gieskes, J.M. (1982) Sr isotopes in interstitial waters of marine sediments from Deep Sea Drilling Project cores, Nature, 300, 493-497.

Expedition 340 Scientists (2012) Lesser Antilles volcanism and landslides: implications for hazard assessment and long-term magmatic evolution of the arc. IODP Prel. Rept., 340. doi:10.2204/ iodp.pr.340.2012

Expedition 340 Scientists (2013) Methods. In Le Friant, A., Ishizuka, O., Stroncik, N.A., and the Expedition 340 Scientists, Proc. IODP, 340: Tokyo (Integrated Ocean Drilling Program Management International, Inc.). doi:10.2204/iodp.proc.340.102.2013.

Fantle, M.S. and DePaolo, D.J. (2006) Sr isotopes and pore fluid chemistry in carbonate sediment of the Ontong Java Plateau: Calcite recrystallization rates and evidence for a rapid rise in seawater Mg over the last 10 million years. Geochim. Cosmochim. Acta, 70, 3883-3904.

Fisher, R.V. and Schmincke, H. (1984) Alteration of volcanic glass, in Pyroclastic Rocks. Springer, p. 312-345.

Fraass A.J. Palmer, M. Martanez-Colan, M. Jutzeler, M. Aljahdali, M. Ishizuka, O. Le Friant, A. Burns, S.J. Hatfield, R. Leckie, M. Wall-Palmer, D. Talling, P.J. (2016) A revised 
Plio-Pleistocene age model and paleoceanography of the northeastern Caribbean Sea: IODP Site U1396 off Montserrat, Lesser Antilles. Stratigraphy, 13, 183-203.

Germa, A. Quidelleur, X. Labanieh, S. Chauvel, C. and Lahitte, P. (2011) The volcanic evolution of Martinique Island: Insights from K-Ar dating into the Lesser Antilles arc migration since the Oligocene. Journal of Volcanology and Geothermal Research, 208, 122-135.

Gieskes, J.M. (1983) The chemistry of interstitial waters of deep-sea sediments: interpretation of deep-sea drilling data. Chemical Oceanography, 8, 221-269.

Gieskes, J.M. and Lawrence, J.R. (1981) Alteration of volcanic matter in deep sea sediments: evidence from the chemical composition of interstitial waters from deep sea drilling cores. Geochim. Cosmochim. Acta, 45, 1687-1703.

Gieskes, J.M., Lawrence, J.R., Perry, E.A., Grady, S.J., Elderfield, H. (1987). Chemistry of interstitial waters and sediments in the Norwegian-Greenland Sea, DSDP Leg 38. Chemical Geology, 63: 143-155.

Gieskes, J.M., Blanc, G., Vrolijk, P., Elderfield, H., Barnes, R. (1990a) Interstitial water chemistry-Major constituents, In:Moore, J.C., Mascle, A., et al., 1990 Proc. ODP, Sci Results, 110, 155- 178.

Gieskes, J.M., Vrolijk, P., and Blanc, G. (1990b) Hydrogeochemistry, ODP Leg 110: An Overview, In:Moore, J.C., Mascle, A., et al., 1990 Proc. ODP, Sci Results, 110, 395408.

Gieskes, J.M. et al. (1990c). Hydrogeochemistry of the Northern Barbados Accretionary Complex Transect: Ocean Drilling Project Leg 110. J. Geophys. Res., 95: 8809-8818

Gilkes, R. and McKenzie, R. (1988) Geochemistry and mineralogy of manganese in soils. In Manganese in soils and plants, Springer, p. 23-35.

Graber, K.K. Pollard, E, Jonasson, B. and Schulte, E. (Eds.), 2002. Overview of Ocean 
Drilling Program engineering tools and hardware. ODP Tech. Note, 31. doi:10.2973/odp.tn.31.2002

Griffin, J.J. Windom, H. and Goldberg, E.D. (1968) The distribution of clay minerals in the world ocean. in Deep Sea Research and Oceanographic Abstracts, 15, 433-459.

Haeckel, M. Van Beusekom, J. Wiesner, M.G. Konig, I. (2001) The impact of the 1994 Mount Pinatubo tephra fallout on the geochemical environment of the deep-sea sediments in the South China Sea. Earth Planetary Science Letters, 193, 151-166.

Hart, S.R. and Staudigel, H. (1982) The control of alkalies and uranium in seawater by ocean crust alteration. Earth and Planetary Science Letters, 58, 202-212.

Hatfield, R. G. (2015) Data report: stratigraphic correlation of Site U1396 and creation of a composite depth scale and splice. In Le Friant, A., Ishizuka, O., Stroncik, N.A., and the Expedition 340 Scientists, Proceedings of the Integrated Ocean Drilling Program, 340: Tokyo (Integrated Ocean Drilling Program Management International, Inc.). doi:10.2204/iodp.proc.340.202.2015

Hein, J.R. O’Neil, J.R. and Jones, M.G. (1979) Origin of authigenic carbonates in sediment from the deep Bering Sea. Sedimentology, 26, 681-705.

Hembury, D.J. Palmer, M.R. Fones, G.R. Mills, R.A. Marsh, R. and Jones, M.T. (2012) Uptake of dissolved oxygen during marine diagenesis of fresh volcanic material. Geochim. Cosmochim. Acta, 84, 353-368.

Hesse, R. and Schacht, U. (2011) Early diagenesis of deep-sea sediments. Deep-Sea Sediments. Developments in Sedimentology, Elsevier, Amsterdam, 63, 557-714. Irwin, H. (1980) Early diagenetic carbonate precipitation and pore fluid migration in the Kimmeridge Clay of Dorset, England. Sedimentology, 27, 577-591.

James, R.H. and Palmer, M.R. (2000) Marine geochemical cycles of the alkali elements and boron: the role of sediments. Geochim. Cosmochim. Acta, 64, 3111- 3122. 
Joseph, C. Torres, M. Martin, R. Haley, B. Pohlman, J. Riedel, M. and Rose, K. (2012) Using the ${ }^{87} \mathrm{Sr} /{ }^{86} \mathrm{Sr}$ of modern and paleoseep carbonates from northern Cascadia to link modern fluid flow to the past. Chemical Geology, 334, 122-130.

Joseph, C., Torres, M.E. Haley, B.A. (2013) Data Report: ${ }^{87} \mathrm{Sr} /{ }^{86} \mathrm{Sr}$ in Pore Fluids from NantroSeize Expeditions 322 and 333. In: Proceedings of the Integrated Ocean Drilling Program (Saito S, Underwood MB, Kubo Y, and the Expedition 322 Scientists) 322: Tokyo (Integrated Ocean Drilling Program Management International, Inc.). doi:10.2204/ iodp.proc.322.204.2013.

Kastner, M. and Gieskes, J.M. (1976) Interstitial water profiles and sites of diagenetic reactions, Leg 35, DSDP, Bellingshausen Abyssal Plain. Earth and Planetary Science Letters, 33, 11-20.

Kutterolf, S. Schacht, U. Wehrmann, H. Freundt, A. and Mőrz, T. (2006) Onshore to offshore tephrostratigraphy and marine ash layer diagenesis: Central America. Geology, Resources, Hazards.Taylor and Francis, London, 395-423.

Lawrence, J.R. Drever, J.I. Anderson, T.F. Brueckner, H.K. (1982) Importance of alteration of volcanic material in the sediments of Deep Sea Drilling Site 323: chemistry, 180/16O and 87Sr/86Sr. Geochim Cosmochim Acta, 43, 573-588.

Le Friant, A. Boudon, G. Deplus, C. and Villemant, B. (2003) Large-scale flank collapse events during the activity of Montagne Pelee, Martinique, Lesser Antilles. Journal of Geophysical Research, 108, 1-15.

Le Friant, A. Ishizuka, O. Stroncik, N.A. and the Expedition 340 Scientists (2013) Proc. IODP, 340: Tokyo (Integrated Ocean Drilling Program Management International, Inc.). doi:10.2204/iodp.proc.340.2013

Le Friant, A. Ishizuka, O. Boudon, G. Palmer, M. Talling, P. Villemant, B. Adachi, T. Aljahdali, M. Breitkreuz, C. and Brunet, M. (2015) Submarine record of volcanic 
island construction and collapse in the Lesser Antilles arc: First scientific drilling of submarine volcanic island landslides by IODP Expedition 340. Geochemistry, Geophysics, Geosystems, 16, 420-442.

Lyons, T. Murray, R. and Pearson, D. (2000) A comparative study of diagenetic pathways in sediments of the Caribbean Sea: Highlights from pore-water results, In Proceedings of the Ocean Drilling Program, scientific results, Vol. 165, p. 287-298.

Macdonald, R. Hawkesworth, C.J. and Heath, E. (2000) The Lesser Antilles volcanic chain: a study in arc magmatism. Earth Science Reviews, 49, 1-76.

Manheim, F.T. (1966) A hydraulic squeezer for obtaining interstitial waters from consolidated and unconsolidated sediments. Geol. Surv. Prof. Pap. (U.S.), 550C:256-261.

Martin, J.B. Kastner, M. Henry, P. Le Pichon, X. and Lallement, S. (1996) Chemical and isotopic evidence for sources of fluids in a mud volcano field seaward of the Barbados accretionary wedge. Journal of Geophysical Research: Solid Earth, 101, 2032520345.

McCanta, M. C. Hatfield, R. G. Thomson, B. J. Hook, S. J. and Fisher, E. (2015) Identifying cryptotephra units using correlated rapid, non-destructive methods: VSWIR spectroscopy, X-ray fluorescence, and magnetic susceptibility, Geochem. Geophys. Geosyst. 16, 4029-4056, doi:10.1002/2015GC005913.

Mucci, A. (1987) Influence of temperature on the composition of magnesian calcite overgrowths precipitated from seawater. Geochim. Cosmochim. Acta, 51, p. 19771984.

Muratli, J.M., Z. Chase, J. McManus and A.C. Mix. (2010) Ice-sheet control of continental erosion in central and southern Chile $\left(36^{\circ}-41^{\circ} \mathrm{S}\right)$ over the last 30,000 years. Quaternary Science Reviews, doi:10.1016/j.quascirev.2010.06.037. 
Muratli, J.M., McManus, J., Mix, A., Chase, Z. (2012) Dissolution of fluoride complexes following microwave-assisted hydrofluoric acid digestion of marine sediments. Talanta, 89, 195-200.

Murray, N.A. (2016) Deep diagenesis in tephra-rich sediments from the Lesser Antilles volcanic arc. MS Thesis, University of Akron, 97 pp.

Murray, N.A. Muralti, J.M. Hartwell, A.M. Megowan, M.R. Goñi, M. and McManus, J. (2016) Data report: Dissolved minor element compositions, sediment major and minor element concentrations, and reactive iron and manganese data from the Lesser Antilles Volcanic Arc region: IODP Expedition 340 Sites U1394, U13995, U1396, U1399, and U1400. In Le Friant, A., Ishizuka, O., Stroncik, N.A., and the Expedition 340 Scientists, Proc. IODP, 340: Tokyo (Integrated Ocean Drilling Program Management International, Inc.). doi:10.2204/iodp.proc.340.207.2016

Paytan, A.M. Kastner, M. Martin, E.E. Macdougall, J.D. Herbert, T. (1993) Marine barite as a monitor of seawater strontium isotope composition, Nature 366, 445-449.

Palmer, M.R. Hatter, S.J. Gernon, T.M. Taylor, R.N. Cassidy, M. Johnson, P. Le Friant, A. and Ishizuka, O. (2016) Discovery of a large 2.4 Ma Plinian eruption of Basse-Terre, Guadeloupe, from the marine sediment record. Geology, 44, 123-126.

Peters, J.L. Murray, R.W. Sparks, J.W. and Coleman, D.S. (2000) Terrigenous matter and dispersed ash in sediment from the Caribbean Sea; results from Leg 165, In Proceedings of the Ocean Drilling Program, Scientific Results, 115-124.

Picard, M. Schneider, J.L. and Boudon, G. (2006) Contrasting sedimentary processes along a convergent margin: the Lesser Antilles arc system. Geo-Mar Letter, 26, 397-410.

Richter, F.M. and DePaolo, D.J. (1988) Diagenesis and Sr isotopic evolution of seawater using data from DSDP 590B and 575. Earth and Planetary Science Letters, 90, 382394. 
Sample, J.C., Torres, M.E., Fisher, A., Hong, W-L., Destrigneville, C., Defliese, W., Tripati, A. (2017) Geochemical constraints on the temperature and timing of carbonate formation and lithification in the Nankai Trough, NanTroSEIZE transect, Geochim. Cosmochim. Acta, 198, 92-114.

Scholz, F. Hensen, C. De Lange, G.J. Haeckel, M. Liebetrau, V. Meixner, A. Reitz, A. and Romer, R.L. (2010) Lithium isotope geochemistry of marine pore waters-insights from cold seep fluids. Geochim. Cosmochim. Acta, 74, 3459-3475.

Scholz, F. Hensen, C. Schmidt, M. and Geersen, J. (2013) Submarine weathering of silicate minerals and the extent of pore water freshening at active continental margins. Geochim. Cosmochim. Acta, 100, 200-216.

Scudder, R.P. Murray, R.W. and Plank, T. (2009) Dispersed ash in deeply buried sediment from the northwest Pacific Ocean: An example from the Izu-Bonin arc (ODP Site 1149). Earth and Planetary Science Letters, 284, 639-648.

Scudder, R.P. Murray, R.W. Schindlbeck, J.C. Kutterolf, S. Hauff, F. and McKinley, C.C. (2014) Regional-scale input of dispersed and discrete volcanic ash to the Izu-Bonin and Mariana subduction zones. Geochemistry, Geophysics, Geosystems, 15, 43694379.

Sigurdsson, H. Leckie, R. and Acton, G. (1997) Caribbean volcanism, Cretaceous/Tertiary impact, and ocean climate history: synthesis of Leg 165. In Proc. ODP, Initial Report, p. 377-400. doi:10.2973/odp.proc.ir.165.108.1997.

Staudigel, H. and Hart, S.R. (1983) Alteration of basaltic glass: Mechanisms and significance for the oceanic crust-seawater budget. Geochim. Cosmochim. Acta, 47, 337-350.

Tang, J. Köhler, S. J. and Dietzel, M. (2008) Sr2+/Ca2+ and 44Ca/40Ca fractionation during inorganic calcite formation: I. Sr incorporation. Geochim. Cosmochim. Acta, 72, 3718-3732. 
Teichert, B. Torres, M. Bohrmann, G. and Eisenhauer, A. (2005) Fluid sources, fluid pathways and diagenetic reactions across an accretionary prism revealed by $\mathrm{Sr}$ and $\mathrm{B}$ geochemistry. Earth and Planetary Science Letters, 239, 106-121.

Torres, M. Cox, T. Hong, W. McManus, J. Sample, J.C. Destrigneville, C. Gan, H. Gan, H. and Moreau, J. (2015) Crustal fluid and ash alteration impacts on the biosphere of Shikoku Basin sediments, Nankai Trough, Japan. Geobiology, 13, 562-580.

Van Lith, Y. Warthmann, R. Vasconcelos, C. and Mckenzie, J.A. (2003) Sulphate reducing bacteria induce low-temperature Ca-dolomite and high Mg-calcite formation. Geobiology, 1, 71-79.

Vrolijk, P., Fisher, A., and Gieskes, J. (1991). Geochemical and geothermal evidence for fluidmigration in the Barbados Accretionary Prism (ODP Leg 110). Geophys. Res. Letters, 18: 947-950

Wallmann, K. Aloisi, G. Haeckel, M. Tishchenko, P. Pavlova, G. Greinert, J. Kutterolf, S. and Eisenhauer, A. (2008) Silicate weathering in anoxic marine sediments. Geochim. Cosmochim. Acta, 72, 2895-2918.

Wall-Palmer, D. Coussens, M. Talling, P.J. Jutzeler, M. Cassidy, M. Marchant, I. Palmer, M.R. Watt, S.F. Smart, C.W. and Fisher, J.K. (2014) Late Pleistocene stratigraphy of IODP Site U1396 and compiled chronology offshore of south and south west Montserrat, Lesser Antilles. Geochemistry, Geophysics, Geosystems, 15, 3000-3020. Warthmann, R. Van Lith, Y. Vasconcelos, C. McKenzie, J.A. and Karpoff, A.M. (2000) Bacterially induced dolomite precipitation in anoxic culture experiments. Geology, 28, 1091-1094. 


\section{FIGURE CAPTIONS}

Figure 1. Map of the Lesser Antilles Volcanic Arc, showing arc migration over time, active volcanoes, and flank collapses. Ages of migrating arc are from Macdonald et al. (2000), flank collapses are modified from Le Friant et al. (2015), and volcano locations are from the Smithsonian Institution, Global Volcanism Program. Gridded bathymetry is in meters and courtesy of the British Oceanographic Data Centre (gebco.net).

Figure 2. Close up of the study area from Expedition 340 cruise in 2012, showing the core locations of interest for this study (U1394, U1395, U1396, U1397, U1398, U1399, and U1400). Flank collapses are modified from Le Friant et al. (2015), volcano locations are from the Smithsonian Institution, Global Volcanism Program, and core coordinates from Expedition 340 Scientists (2012). Gridded bathymetry is in meters and courtesy of the British Oceanographic Data Centre (gebco.net).

Figure 3. Dissolved solute distributions for Site U1394. (A) Alkalinity and $\mathrm{NH}_{4}$, (B) $\mathrm{SO}_{4}{ }^{2-}$ and $\mathrm{Mn},(\mathrm{C}) \mathrm{Ca}$ and $\mathrm{Mg}$, (D) K and Li, (E) Si, and (F) Sr. Dashed lines denote bottom water concentrations. Alkalinity, $\mathrm{NH}_{4}, \mathrm{Ca}, \mathrm{Mg}$, and $\mathrm{SO}_{4}{ }^{2-}$ data are from Le Friant et al. (2013) and minor ion data is from Murray et al. (2016).

Figure 4. Dissolved solute distributions for Site U1395. (A) Alkalinity and $\mathrm{NH}_{4}$, (B) $\mathrm{SO}_{4}{ }^{2-}$ and Mn, (C) Ca and Mg, (D) K and Li, (E) Si, and (F) Sr. Dashed lines denote bottom water 
concentrations. Alkalinity, $\mathrm{NH}_{4}, \mathrm{Ca}, \mathrm{Mg}$, and $\mathrm{SO}_{4}{ }^{2-}$ data are from Le Friant et al. (2013) and minor ion data is from Murray et al. (2016).

Figure 5. Dissolved solute distributions for Site U1396. (A) Alkalinity and $\mathrm{NH}_{4}$, (B) $\mathrm{SO}_{4}{ }^{2-}$ and $\mathrm{Mn},(\mathrm{C}) \mathrm{Ca}$ and $\mathrm{Mg}$, (D) K and Li, (E) Si, and (F) Sr. Dashed lines denote bottom water concentrations. Alkalinity, $\mathrm{NH}_{4}, \mathrm{Ca}, \mathrm{Mg}$, and $\mathrm{SO}_{4}{ }^{2-}$ data are from Le Friant et al. (2013) and minor ion data is from Murray et al. (2016).

Figure 6. Dissolved solute distributions for Site U1397. (A) Alkalinity and $\mathrm{NH}_{4}$, (B) $\mathrm{SO}_{4}{ }^{2-}$ and $\mathrm{Mn},(\mathrm{C}) \mathrm{Ca}$ and $\mathrm{Mg}$, (D) $\mathrm{K}$ and $\mathrm{Li}$, (E) Si, and (F) Sr and ${ }^{87} \mathrm{Sr} /{ }^{86} \mathrm{Sr}$. Dashed lines denote bottom water concentrations. Alkalinity, $\mathrm{NH}_{4}, \mathrm{Ca}, \mathrm{Mg}$, and $\mathrm{SO}_{4}{ }^{2-}$ data are from Le Friant et al. (2013) and minor ion data is from Murray et al. (2016).

Figure 7. Dissolved solute distributions for Site U1398. (A) Alkalinity and $\mathrm{NH}_{4}$, (B) $\mathrm{SO}_{4}{ }^{2-}$ and $\mathrm{Mn},(\mathrm{C}) \mathrm{Ca}$ and $\mathrm{Mg}$, (D) $\mathrm{K}$ and $\mathrm{Li}$, (E) Si, and (F) Sr and ${ }^{87} \mathrm{Sr} /{ }^{86} \mathrm{Sr}$. Dashed lines denote bottom water concentrations. Alkalinity, $\mathrm{NH}_{4}, \mathrm{Ca}, \mathrm{Mg}$, and $\mathrm{SO}_{4}{ }^{2-}$ data are from Le Friant et al. (2013) and minor ion data is from Murray et al. (2016).

Figure 8. Dissolved solute distributions for Site U1399. (A) Alkalinity and $\mathrm{NH}_{4}$, (B) $\mathrm{SO}_{4}{ }^{2-}$ and $\mathrm{Mn},(\mathrm{C}) \mathrm{Ca}$ and $\mathrm{Mg}$, (D) $\mathrm{K}$ and $\mathrm{Li}$, (E) Si, and (F) Sr and ${ }^{87} \mathrm{Sr} /{ }^{86} \mathrm{Sr}$. Dashed lines denote bottom water concentrations. Alkalinity, $\mathrm{NH}_{4}, \mathrm{Ca}, \mathrm{Mg}$, and $\mathrm{SO}_{4}{ }^{2-}$ data are from Le Friant et al. (2013) and minor ion data is from Murray et al. (2016).

Figure 9. Dissolved solute distributions for Site U1400. (A) Alkalinity and $\mathrm{NH}_{4}$, (B) $\mathrm{SO}_{4}{ }^{2-}$ and $\mathrm{Mn},(\mathrm{C}) \mathrm{Ca}$ and $\mathrm{Mg}$, (D) Si and $\mathrm{Li}$, and (E) $\mathrm{Sr}$ and ${ }^{87} \mathrm{Sr} /{ }^{86} \mathrm{Sr}$. Dashed lines denote bottom water concentrations. Alkalinity, $\mathrm{NH}_{4}, \mathrm{Ca}, \mathrm{Mg}$, and $\mathrm{SO}_{4}{ }^{2-}$ data are from Le Friant et al. (2013) and minor ion data is from Murray et al. (2016).

Figure 10. ${ }^{87} \mathrm{Sr} /{ }^{86} \mathrm{Sr}$ in fluids and solid phases plotted as a function of age from Site U1396. Data are from the carbonate fraction, the residual non-carbonate fraction, and the pore fluids. Age calculations are derived from (Hatfield, 2015; Coussens et al., 2016) and dashed line represents the strontium isotope value of contemporaneous seawater (Elderfield, 1982; Paytan et al., 1993).

Figure 11. Dissolved $\mathrm{Mg}$ and Ca displaying the two dominant diagenetic reactions occurring in the Grenada Basin for the [A] northern sites U1394, U1395, and U1396 [B] southern sites U1399 and U1400. Data from sites 998, 999, 1000, and 1001 are plotted with data from this study for comparison [C, D] and are taken from Lyons et al. (2000). Data from site 671, which lies to the east within the northern Barbados accretionary complex are from Gieskes et al., 1990a.

Figure 12. ${ }^{87} \mathrm{Sr} /{ }^{86} \mathrm{Sr}$ plotted as a function of $1 / \mathrm{Sr}$ in pore fluids. The gray box indicates $\mathrm{Sr}$ isotope compositions characteristic of the most recent $\sim 4 \mathrm{Ma}$ (Elderfield, 1986). Data to the right of the figure are those exhibiting removal of Sr from pore fluids, relative to the seawater value. Data to the left of the figure are those samples exhibiting Sr enrichment in the pore fluids. Note that the Sr isotope values of the pore waters at Site U1396 have the lowest ${ }^{87} \mathrm{Sr}$ ${ }^{86} \mathrm{Sr}$ values of any of the cores suggesting that this site is the most impacted by reaction with volcanogenic material.

Figure 13. Calcite saturation state calculations for sites U1394, 1398, and 1399. Note that most values are supersaturated with respect to calcite; however, the large uncertainties in 
these calculations, including the values for $\mathrm{pH}$, likely mean that the relative saturation states are uncertain, as discussed within the text.

Figure 14. Dissolved minor phases that can be incorporated into the carbonate phase; (A) Mn for site U1394 (B) Mn and Sr for site U1399. Note that there is not a correlation between Sr and Ca for site U1394, which may imply that carbonate precipitation is not what is driving the correlation for site U1399. 
Figure 1. Map of the Lesser Antilles Volcanic Arc, showing arc migration over time, active volcanoes, and flank collapses. Ages of migrating arc are from Macdonald et al. (2000), flank collapses are modified from Le Friant et al. (2015), and volcano locations are from the Smithsonian Institution, Global Volcanism Program. Gridded bathymetry is in meters and courtesy of the British Oceanographic Data Centre (gebco.net).

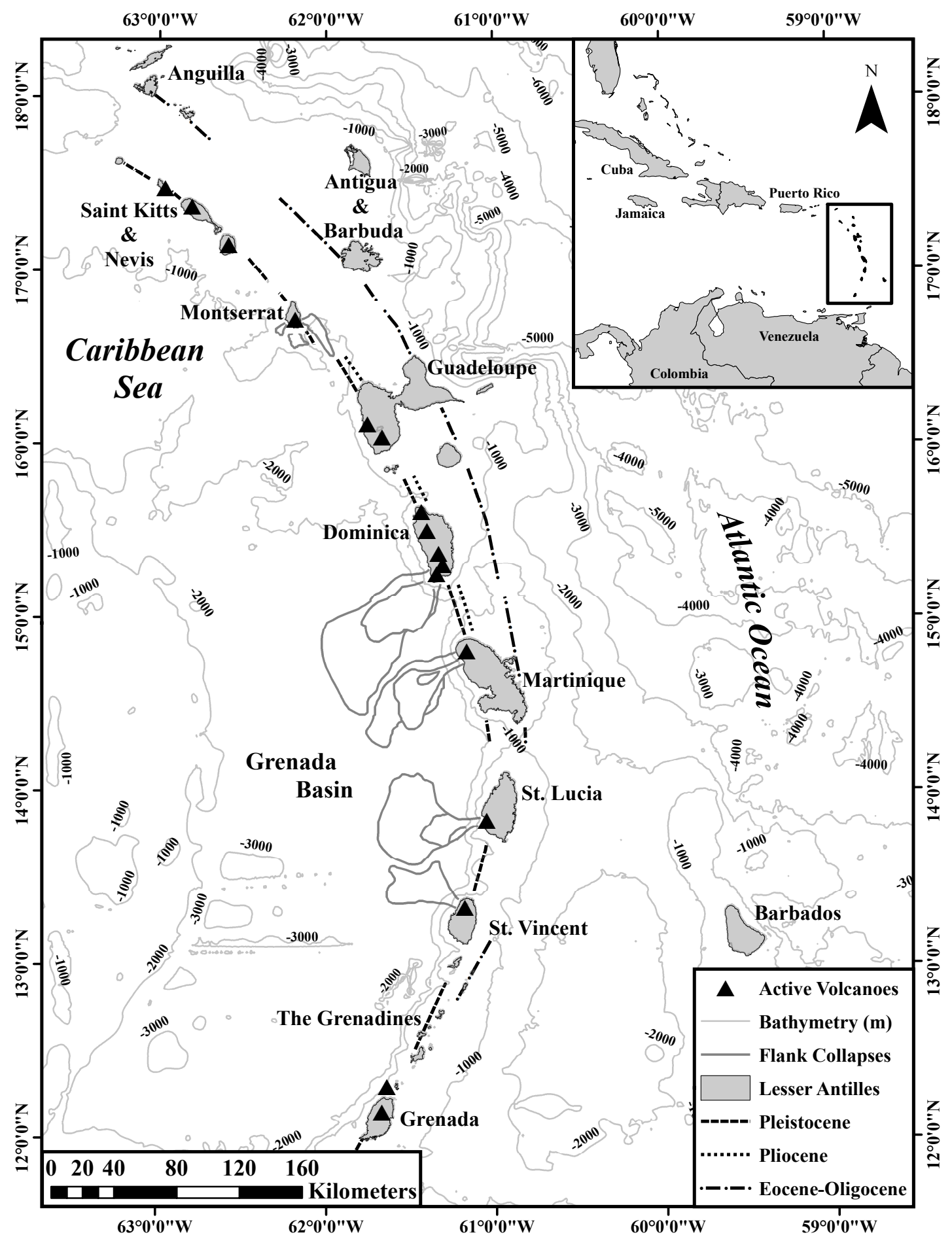


Figure 2. Close up of the study area from Expedition 340 cruise in 2012, showing the core locations of interest for this study (U1394, U1395, U1396, U1397, U1398, U1399, and U1400). Flank collapses are modified from Le Friant et al. (2015), volcano locations are from the Smithsonian Institution, Global Volcanism Program, and core coordinates from Expedition 340 Scientists (2012). Gridded bathymetry is in meters and courtesy of the British Oceanographic Data Centre (gebco.net).

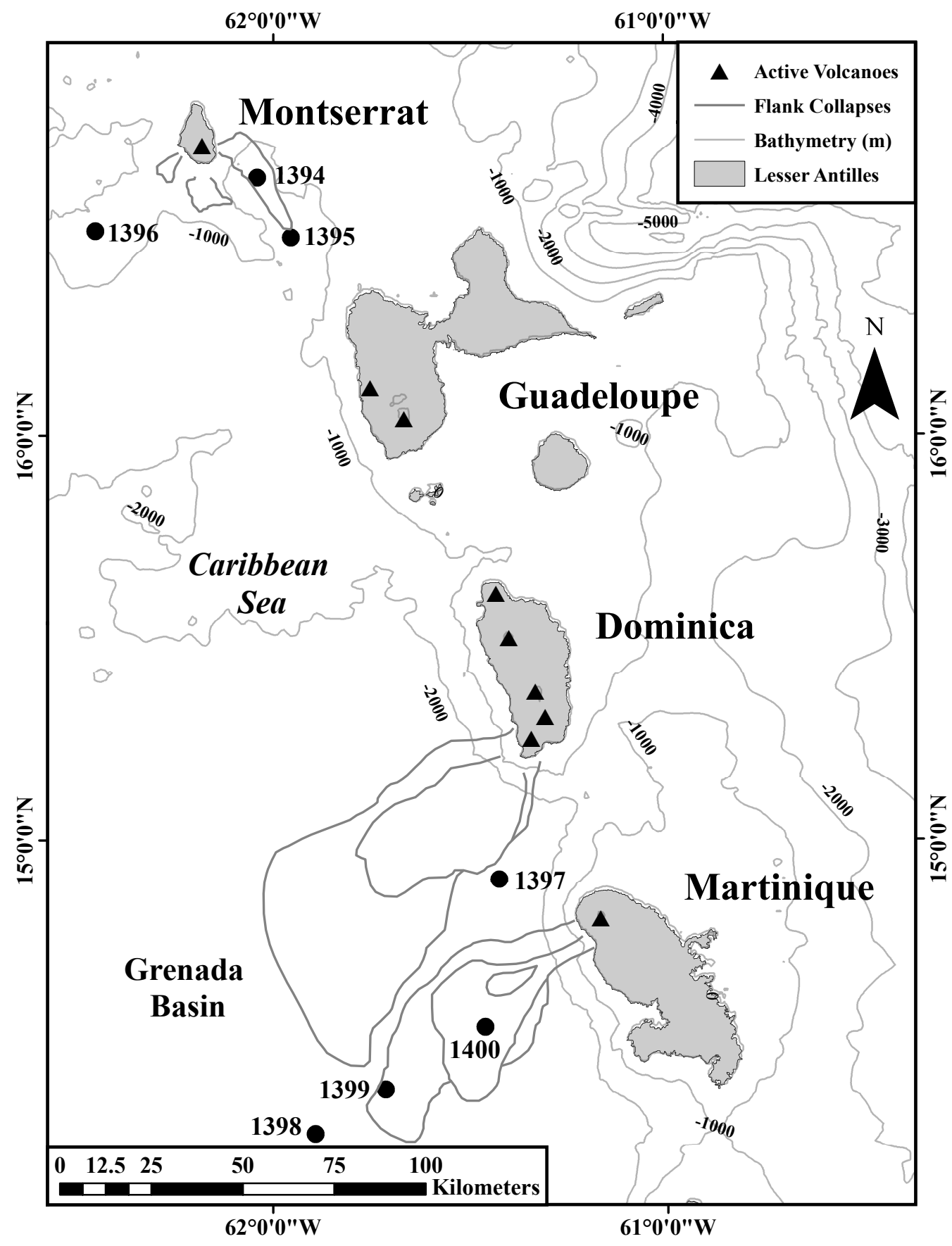


Figure 3. Dissolved solute distributions for Site U1394. (A) Alkalinity and $\mathrm{NH}_{4}$, (B) $\mathrm{SO}_{4}{ }^{2-}$ and $\mathrm{Mn}$, (C) $\mathrm{Ca}$ and $\mathrm{Mg}$, (D) $\mathrm{K}$ and $\mathrm{Li}$, (E) Si, and (F) Sr. Dashed lines denote bottom water concentrations. Alkalinity, $\mathrm{NH}_{4}, \mathrm{Ca}, \mathrm{Mg}$, and $\mathrm{SO}_{4}{ }^{2-}$ data are from Le Friant et al. (2013) and minor ion data is from Murray et al. (2016).

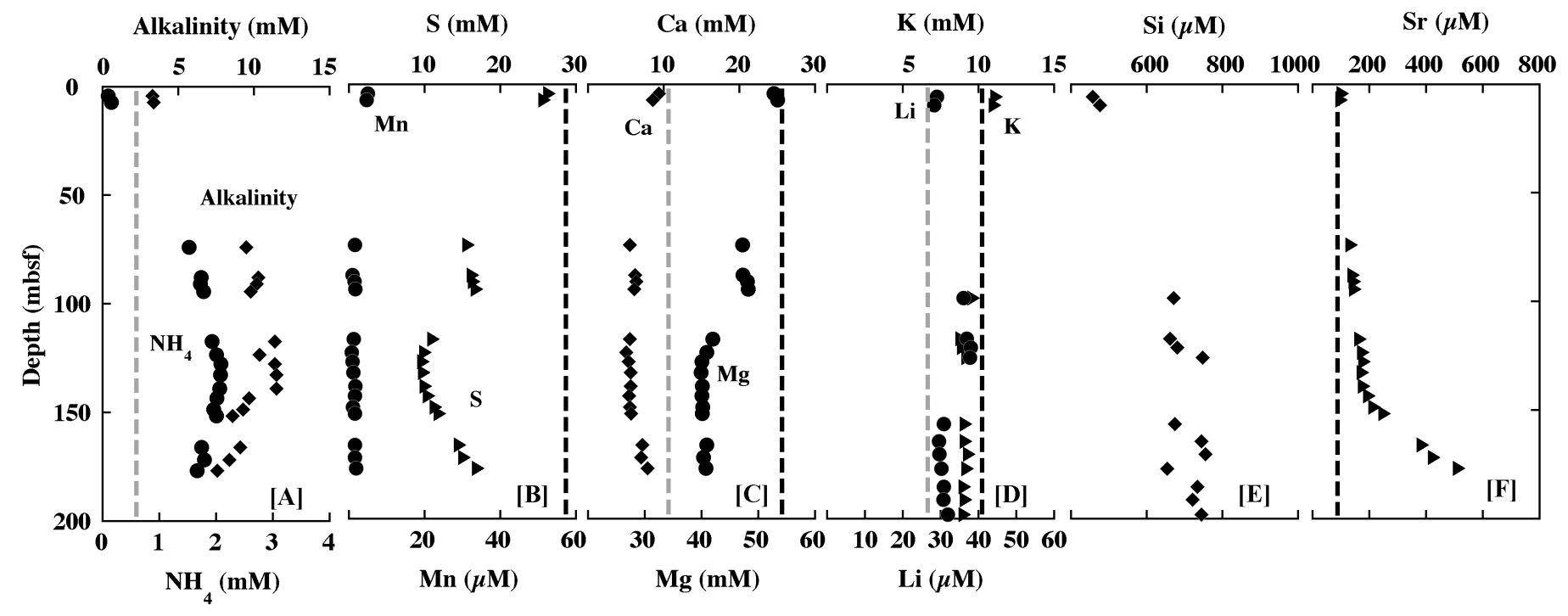


Figure 4. Dissolved solute distributions for Site U1395. (A) Alkalinity and $\mathrm{NH}_{4}$, (B) $\mathrm{SO}_{4}{ }^{2-}$ and $\mathrm{Mn}$, (C) $\mathrm{Ca}$ and $\mathrm{Mg}$, (D) K and Li, (E) Si, and (F) Sr. Dashed lines denote bottom water concentrations. Alkalinity, $\mathrm{NH}_{4}, \mathrm{Ca}, \mathrm{Mg}$, and $\mathrm{SO}_{4}{ }^{2-}$ data are from Le Friant et al. (2013) and minor ion data is from Murray et al. (2016).




Figure 5. Dissolved solute distributions for Site U1396. (A) Alkalinity and $\mathrm{NH}_{4}$, (B) $\mathrm{SO}_{4}{ }^{2-}$ and $\mathrm{Mn},(\mathrm{C}) \mathrm{Ca}$ and $\mathrm{Mg}$, (D) $\mathrm{K}$ and $\mathrm{Li}$, (E) Si, and (F) Sr. Dashed lines denote bottom water concentrations. Alkalinity, $\mathrm{NH}_{4}, \mathrm{Ca}, \mathrm{Mg}$, and $\mathrm{SO}_{4}{ }^{2-}$ data are from Le Friant et al. (2013) and minor ion data is from Murray et al. (2016).

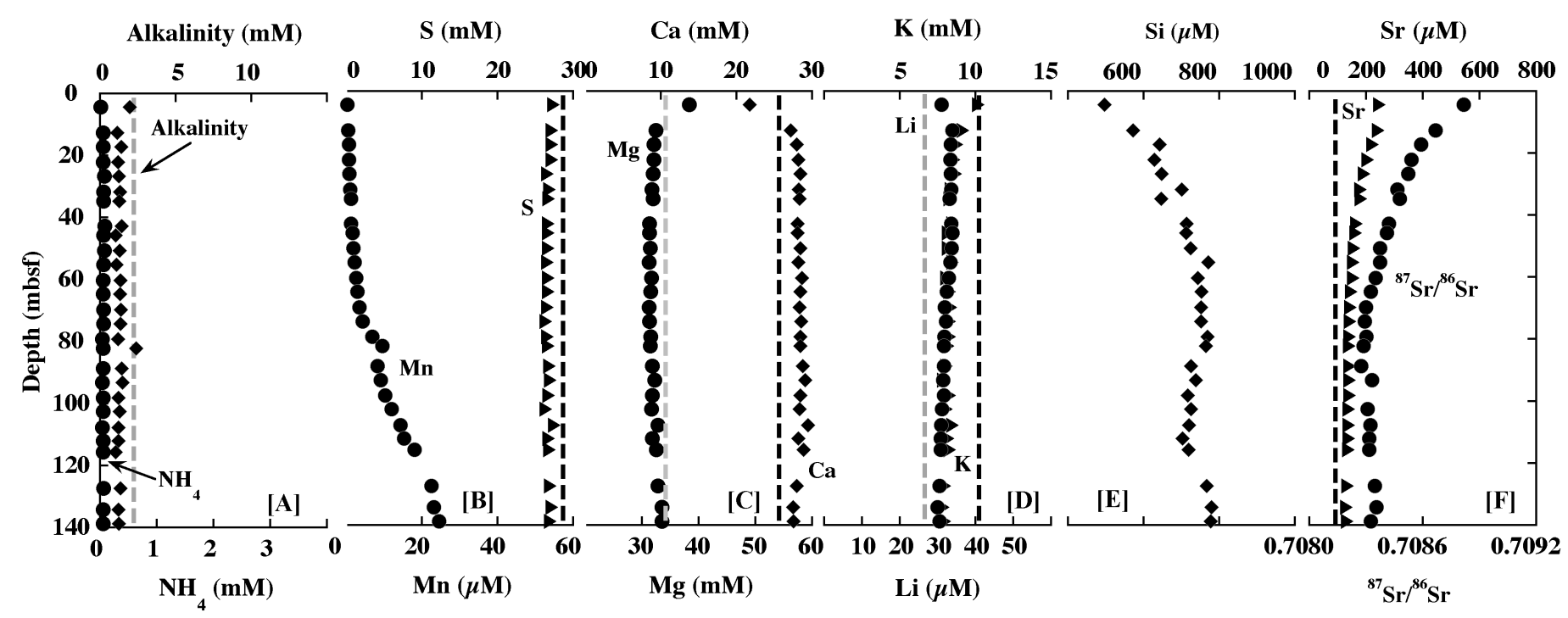


Figure 6. Dissolved solute distributions for Site U1397. (A) Alkalinity and $\mathrm{NH}_{4}$, (B) $\mathrm{SO}_{4}{ }^{2-}$ and $\mathrm{Mn},(\mathrm{C}) \mathrm{Ca}$ and $\mathrm{Mg}$, (D) $\mathrm{K}$ and $\mathrm{Li}$, (E) $\mathrm{Si}$, and (F) $\mathrm{Sr}$ and ${ }^{87} \mathrm{Sr} /{ }^{86} \mathrm{Sr}$. Dashed lines denote bottom water concentrations. Alkalinity, $\mathrm{NH}_{4}, \mathrm{Ca}, \mathrm{Mg}$, and $\mathrm{SO}_{4}{ }^{2-}$ data are from Le Friant et al. (2013) and minor ion data is from Murray et al. (2016).

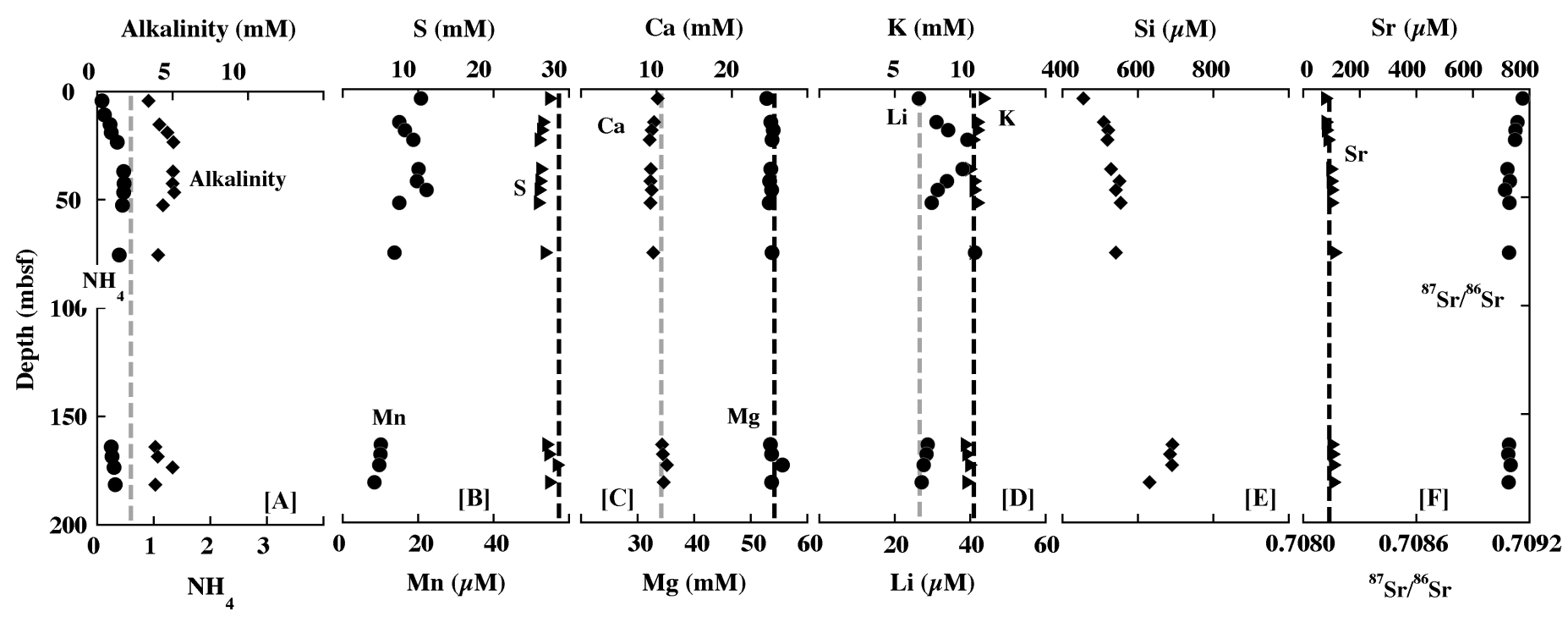


Figure 7. Dissolved solute distributions for Site U1398. (A) Alkalinity and $\mathrm{NH}_{4}$, (B) $\mathrm{SO}_{4}{ }^{2-}$ and $\mathrm{Mn}$, (C) Ca and $\mathrm{Mg}$, (D) K and Li, (E) Si, and (F) Sr and ${ }^{87} \mathrm{Sr} /{ }^{86} \mathrm{Sr}$. Dashed lines denote bottom water concentrations. Alkalinity, $\mathrm{NH}_{4}, \mathrm{Ca}, \mathrm{Mg}$, and $\mathrm{SO}_{4}{ }^{2-}$ data are from Le Friant et al. (2013) and minor ion data is from Murray et al. (2016).

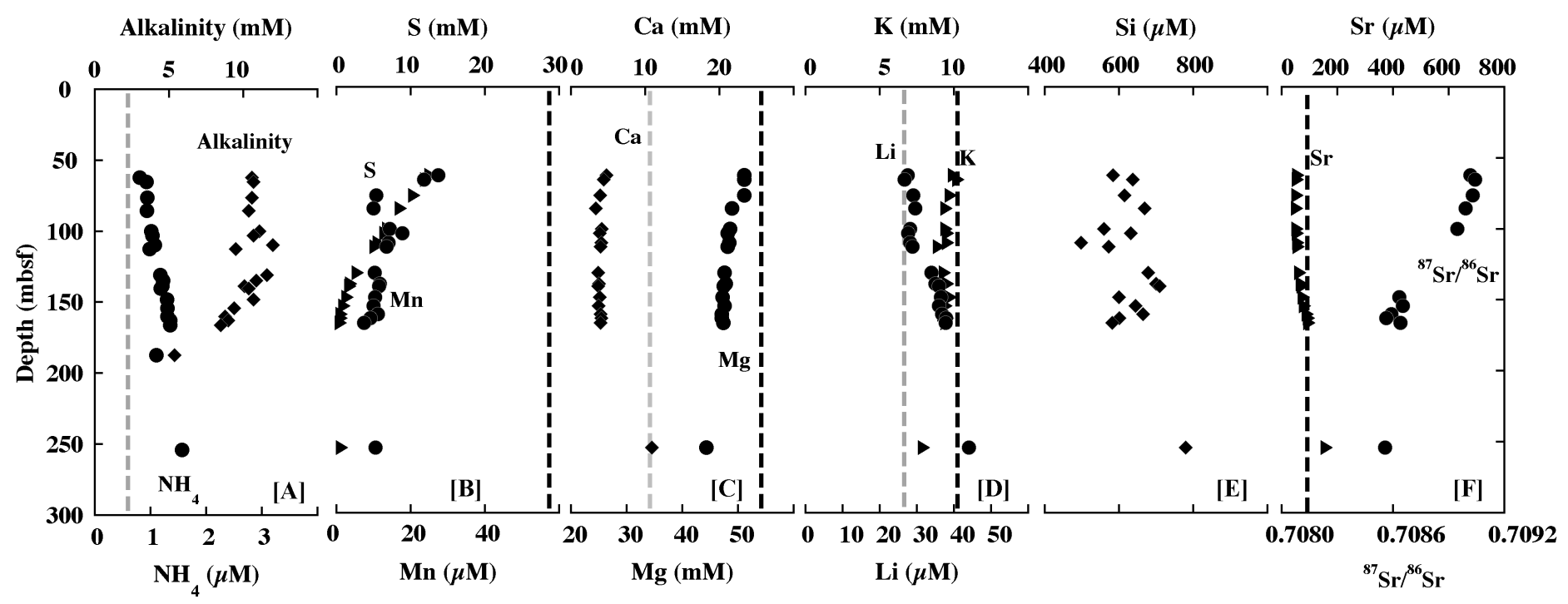


Figure 8. Dissolved solute distributions for Site U1399. (A) Alkalinity and $\mathrm{NH}_{4}$, (B) $\mathrm{SO}_{4}{ }^{2-}$ and $\mathrm{Mn},(\mathrm{C}) \mathrm{Ca}$ and $\mathrm{Mg}$, (D) $\mathrm{K}$ and $\mathrm{Li}$, (E) $\mathrm{Si}$, and (F) $\mathrm{Sr}$ and ${ }^{87} \mathrm{Sr} /{ }^{86} \mathrm{Sr}$. Dashed lines denote bottom water concentrations. Alkalinity, $\mathrm{NH}_{4}, \mathrm{Ca}, \mathrm{Mg}$, and $\mathrm{SO}_{4}{ }^{2-}$ data are from Le Friant et al. (2013) and minor ion data is from Murray et al. (2016).

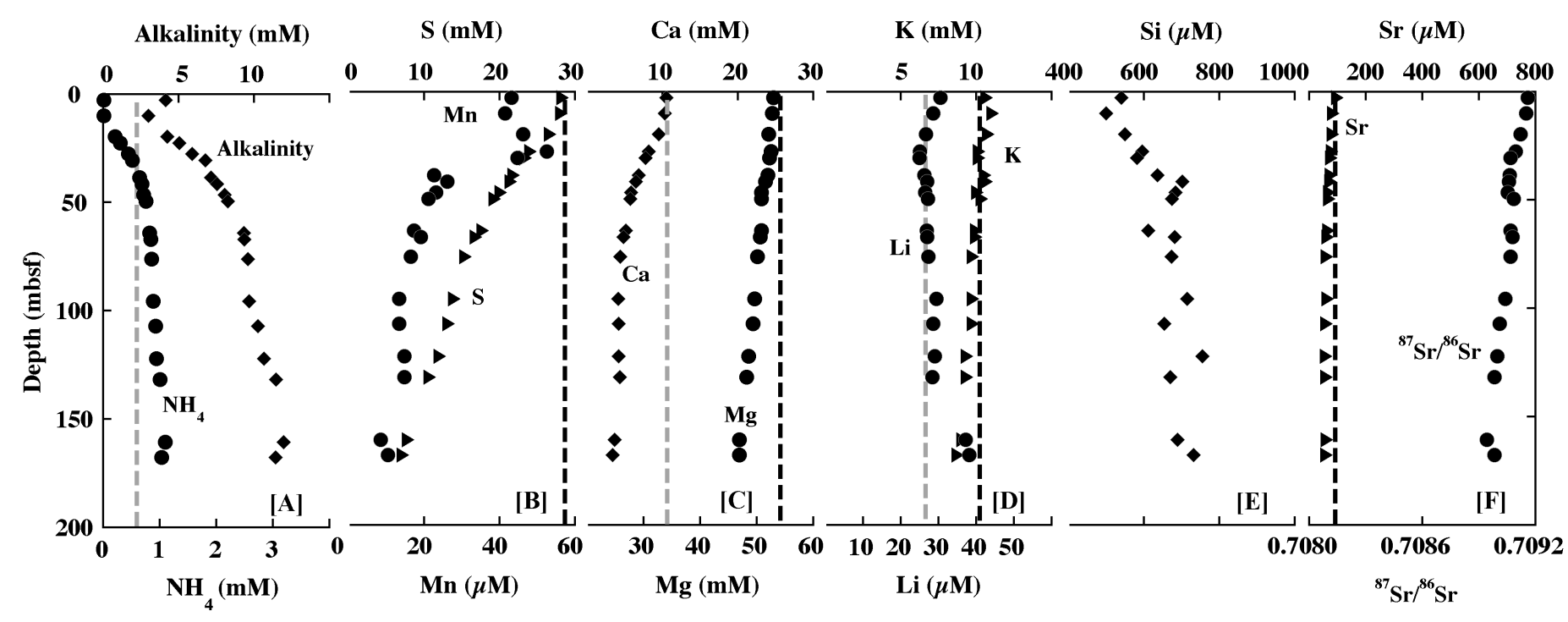


Figure 9. Dissolved solute distributions for Site U1400. (A) Alkalinity and $\mathrm{NH}_{4}$, (B) $\mathrm{SO}_{4}{ }^{2-}$ and $\mathrm{Mn},(\mathrm{C}) \mathrm{Ca}$ and $\mathrm{Mg}$, (D) $\mathrm{Si}$ and $\mathrm{Li}$, and (E) $\mathrm{Sr}$ and ${ }^{87} \mathrm{Sr} /{ }^{86} \mathrm{Sr}$. Dashed lines denote bottom water concentrations. Alkalinity, $\mathrm{NH}_{4}, \mathrm{Ca}, \mathrm{Mg}$, and $\mathrm{SO}_{4}{ }^{2-}$ data are from Le Friant et al. (2013) and minor ion data is from Murray et al. (2016).

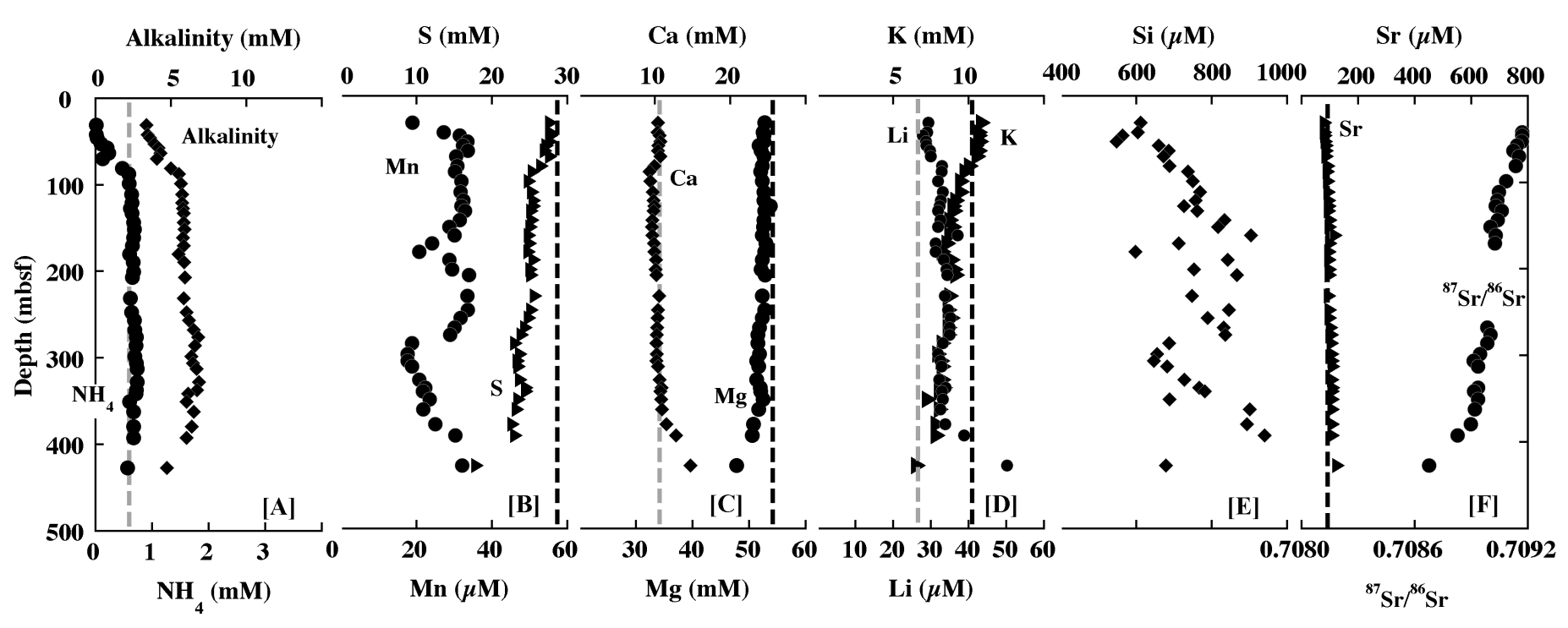


Figure 10. ${ }^{87} \mathrm{Sr} /{ }^{86} \mathrm{Sr}$ in fluids and solid phases plotted as a function of age from Site U1396. Data are from the carbonate fraction, the residual non-carbonate fraction, and the pore fluids. Age calculations are derived from (Hatfield, 2015; Coussens et al., 2016) and dashed line represents the strontium isotope value of contemporaneous seawater (Elderfield, 1982; Paytan et al., 1993).

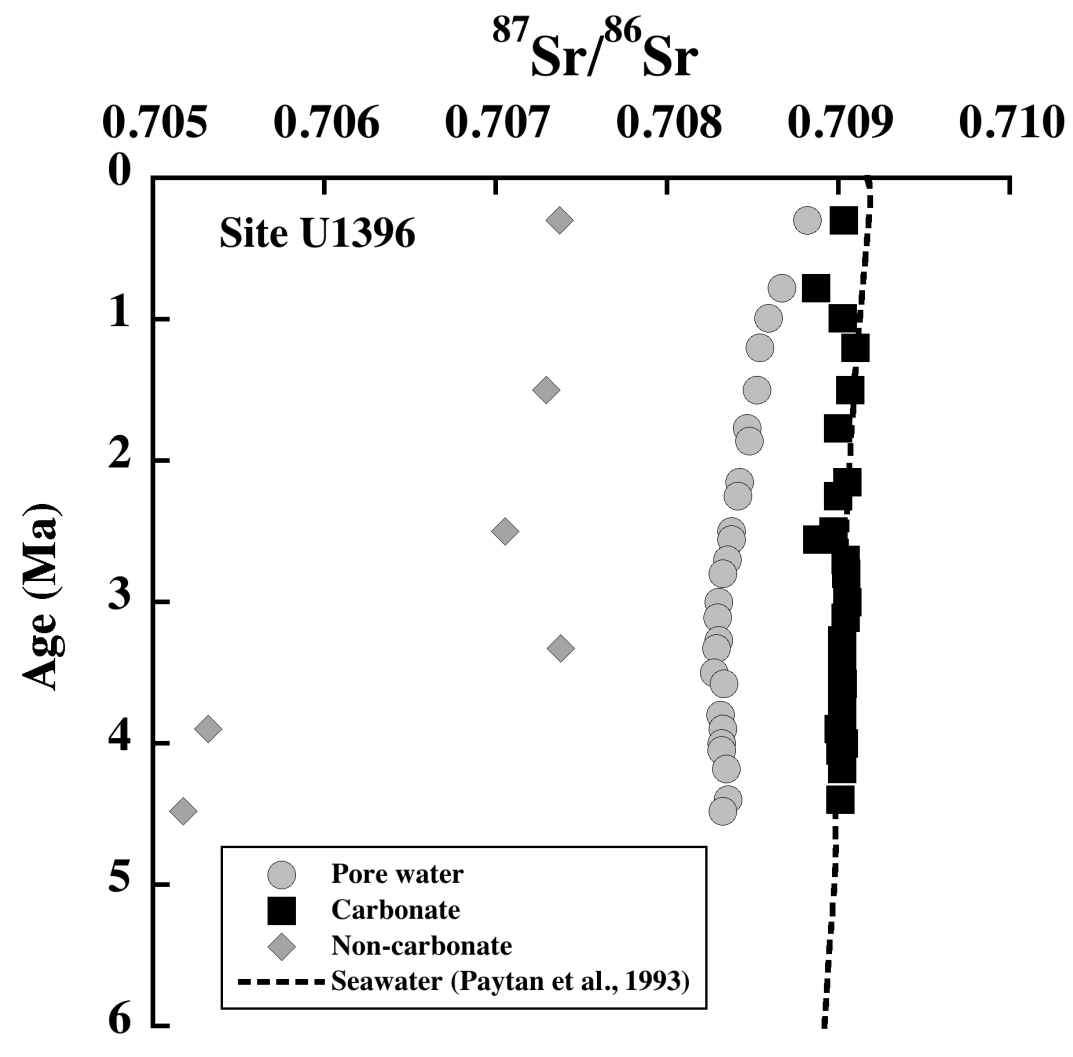


Figure 11. Dissolved $\mathrm{Mg}$ and $\mathrm{Ca}$ displaying the two dominant diagenetic reactions occurring in the Grenada Basin for the [A] northern sites U1394, U1395, and U1396 [B] southern sites U1399 and U1400. Data from sites 998, 999, 1000, and 1001 are plotted with data from this study for comparison [C, D] and are taken from Lyons et al. (2000). Data from site 671 , which lies to the east within the northern Barbados accretionary complex are from Gieskes et al., 1990a.
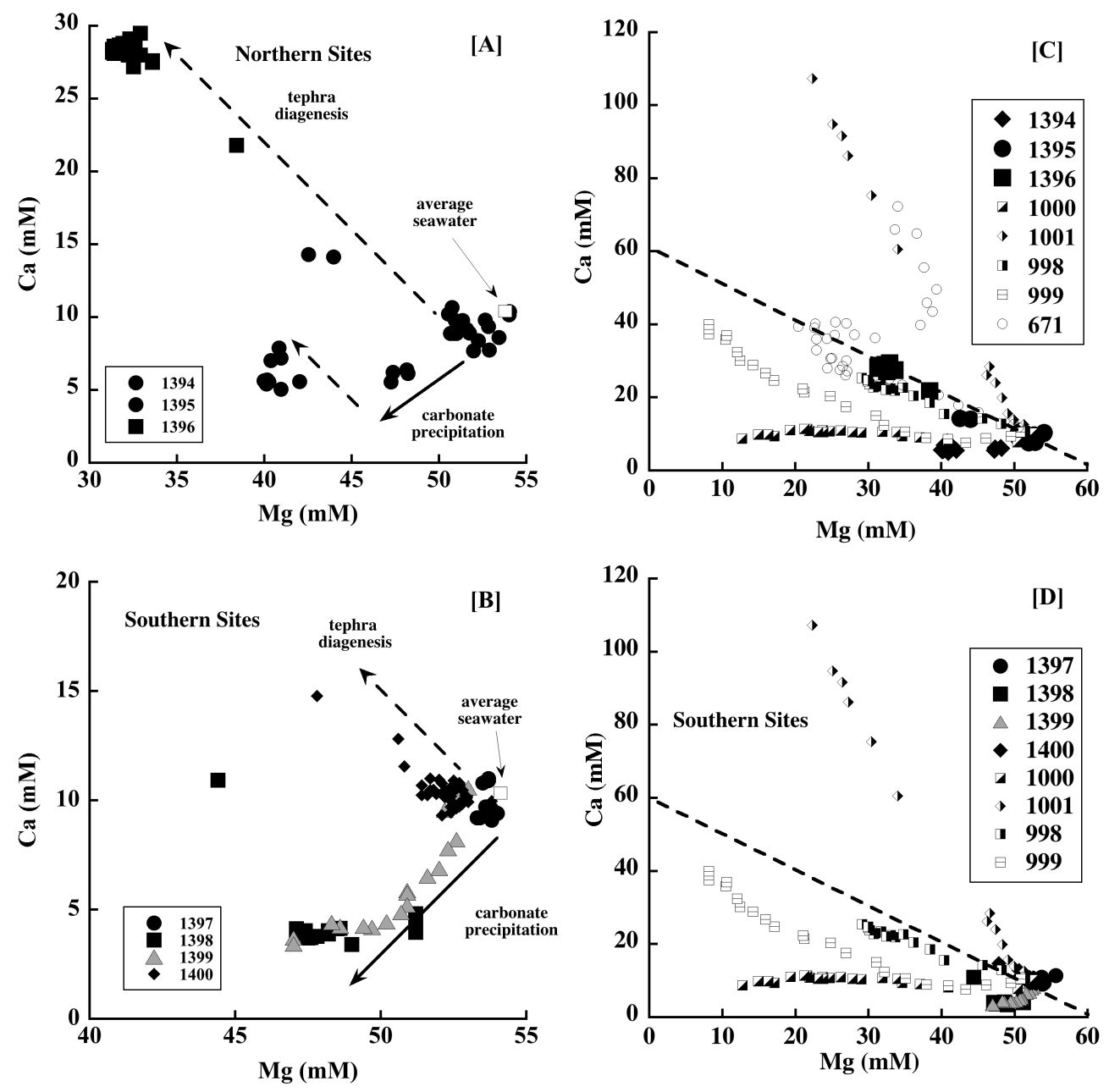
Figure 12. ${ }^{87} \mathrm{Sr} /{ }^{86} \mathrm{Sr}$ plotted as a function of $1 / \mathrm{Sr}$ in pore fluids. The gray box indicates $\mathrm{Sr}$ isotope compositions characteristic of the most recent $4 \mathrm{Ma}$ (Elderfield, 1986). Data to the right of the figure are those exhibiting removal of $\mathrm{Sr}$ from pore fluids, relative to the seawater value. Data to the left of the figure are those samples exhibiting $\mathrm{Sr}$ enrichment in the pore fluids. Note that the Sr isotope values of the pore waters at Site U1396 have the lowest ${ }^{87} \mathrm{Sr} /{ }^{86} \mathrm{Sr}$ values of any of the cores suggesting that this site is the most impacted by reaction with volcanogenic material.

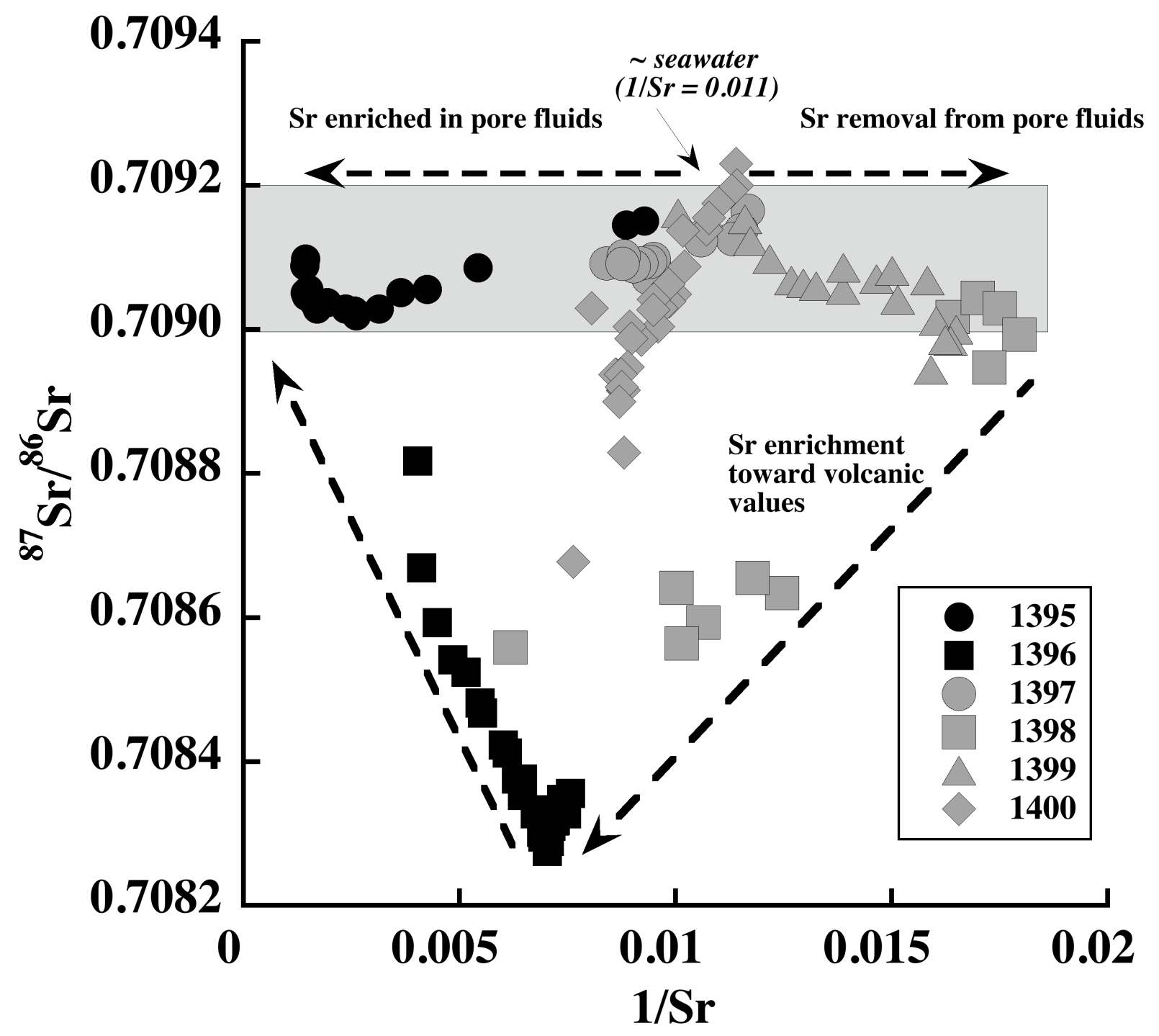


Figure 13. Calcite and aragonite saturation state calculations for sites U1394, 1398, and 1399. Note that most values are supersaturated with respect to calcite; however, the large uncertainties in these calculations, including the values for $\mathrm{pH}$, likely mean that the relative saturation states are uncertain, as discussed within the text.
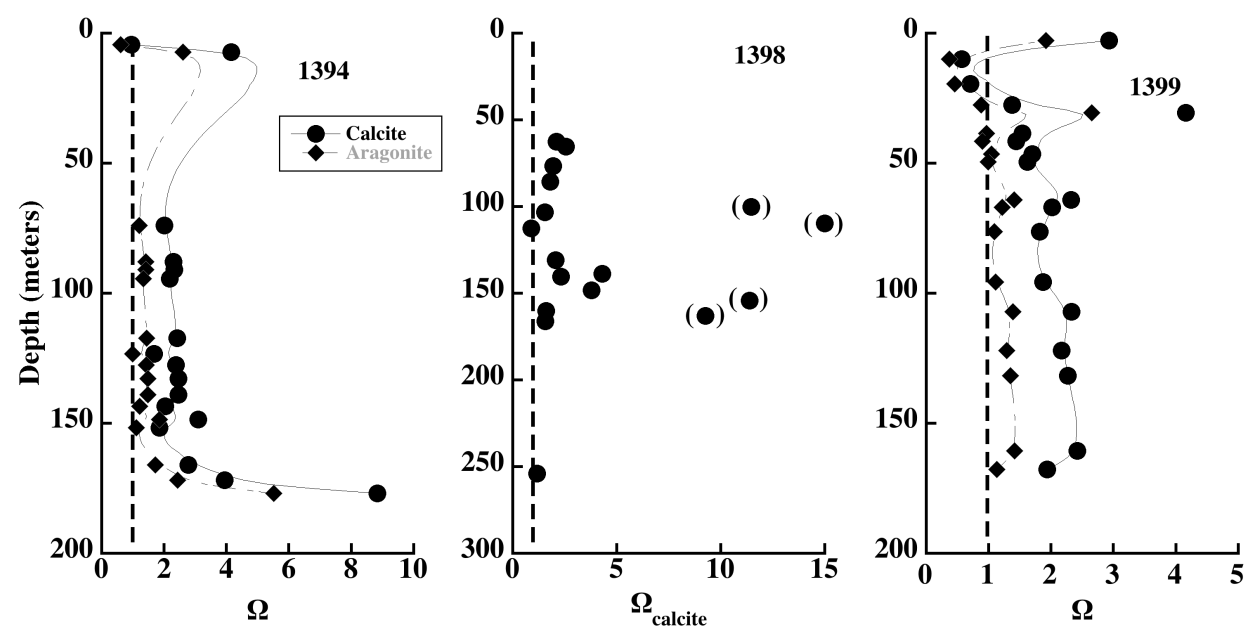
Figure 14. Dissolved minor phases that can be incorporated into the carbonate phase; (A) Mn for site U1394 (B) Mn and Sr for site U1399. Note that there is not a correlation between Sr and $\mathrm{Ca}$ for site U1394, which may imply that carbonate precipitation is not what is driving the correlation for site U1399.
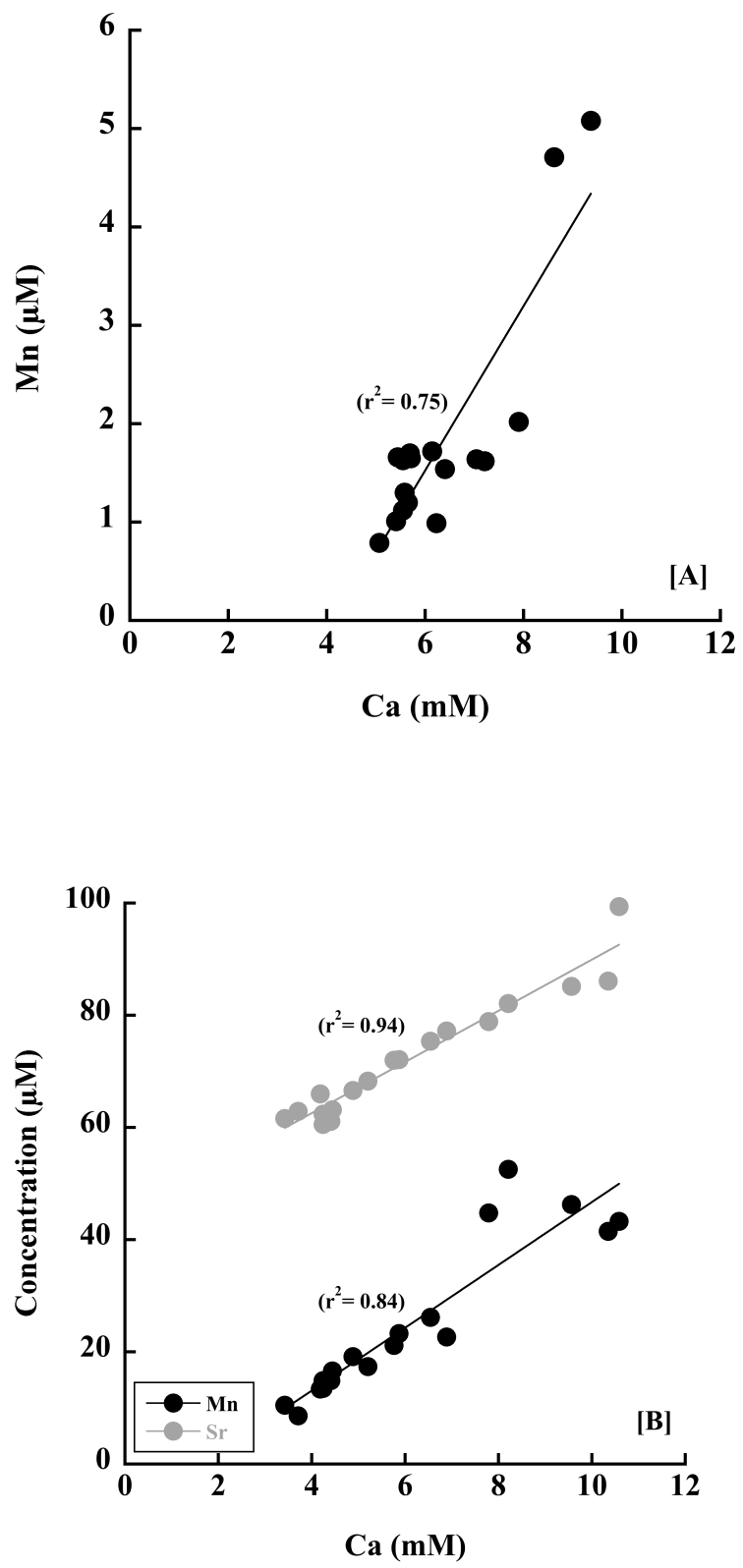
Table A1. Sr isotope composition of interstitial pore fluid samples.

\begin{tabular}{|c|c|c|c|c|c|c|c|c|}
\hline Core & Type & Section & $\begin{array}{c}\text { Top } \\
\text { Depth } \\
\text { (CSF-A) }\end{array}$ & $\begin{array}{c}\text { Bottom } \\
\text { Depth } \\
\text { (CSF-A) }\end{array}$ & $\operatorname{Sr}(\mu \mathrm{M})$ & \pm & ${ }^{87} \mathrm{Sr} /{ }^{86} \mathrm{Sr}$ & \pm \\
\hline \multicolumn{9}{|c|}{ 340-U1395B- } \\
\hline 1 & $\mathrm{H}$ & 3 & 4.4 & 4.5 & 107.8 & 0.7 & 0.709151 & 0.000006 \\
\hline 2 & $\mathrm{H}$ & 3 & 10.3 & 10.4 & 112.8 & 0.6 & 0.709145 & 0.000007 \\
\hline 3 & $\mathrm{H}$ & 5 & 22.7 & 22.8 & 184.2 & 1.2 & 0.709086 & 0.000004 \\
\hline 4 & $\mathrm{H}$ & 3 & 29.32 & 29.42 & 235.4 & 4.8 & 0.709056 & 0.000007 \\
\hline 4 & $\mathrm{H}$ & 6 & 33.88 & 33.98 & 274.8 & 5.3 & 0.709051 & 0.000006 \\
\hline 5 & $\mathrm{H}$ & 3 & 38.8 & 38.9 & 318.5 & 5.2 & 0.709028 & 0.000008 \\
\hline 6 & $\mathrm{H}$ & 4 & 49.72 & 49.82 & 382.3 & 5.1 & 0.709019 & 0.000008 \\
\hline 6 & $\mathrm{H}$ & 6 & 52.85 & 52.95 & 389.6 & 5.8 & 0.709026 & 0.000007 \\
\hline 7 & $\mathrm{H}$ & 4 & 59.31 & 59.41 & 422.3 & 5.5 & 0.709029 & 0.000006 \\
\hline 9 & $\mathrm{H}$ & 1 & 72.6 & 72.7 & 515.6 & 5.3 & 0.709037 & 0.000006 \\
\hline 10 & $\mathrm{H}$ & 2 & 82.3 & 82.4 & 583.8 & 4.7 & 0.709033 & 0.000007 \\
\hline 10 & $\mathrm{H}$ & 5 & 86.81 & 86.91 & 585.0 & 5.7 & 0.709029 & 0.000007 \\
\hline 11 & $\mathrm{H}$ & 3 & 92.1 & 92.2 & 613.6 & 6.0 & 0.709038 & 0.000008 \\
\hline 12 & $\mathrm{H}$ & 3 & 101.15 & 101.25 & 643.9 & 6.2 & 0.709044 & 0.000009 \\
\hline 12 & $\mathrm{H}$ & 6 & 105.7 & 105.8 & 663.4 & 5.0 & 0.709056 & 0.000006 \\
\hline 13 & $\mathrm{H}$ & 4 & 112.02 & 112.12 & 689.2 & 5.2 & 0.709046 & 0.000009 \\
\hline 14 & $\mathrm{H}$ & 3 & 117.3 & 117.4 & 698.4 & 6.8 & 0.709051 & 0.000009 \\
\hline 24 & $\mathrm{X}$ & 1 & 185.5 & 185.6 & 694.3 & 7.3 & 0.709098 & 0.000007 \\
\hline 25 & $\mathrm{X}$ & 1 & 195.1 & 195.2 & 706.3 & 4.7 & 0.709088 & 0.000008 \\
\hline \multicolumn{9}{|c|}{ 340-U1396C- } \\
\hline 1 & $\mathrm{H}$ & 3 & 4.4 & 4.5 & 248.2 & 5 & 0.708817 & 0.000007 \\
\hline 2 & $\mathrm{H}$ & 3 & 12.8 & 12.9 & 242.7 & 5 & 0.708669 & 0.000004 \\
\hline 2 & $\mathrm{H}$ & 6 & 17.3 & 17.4 & 222.9 & 5 & 0.708593 & 0.000033 \\
\hline 3 & $\mathrm{H}$ & 3 & 22.2 & 22.3 & 206.7 & 5 & 0.708577 & 0.000006 \\
\hline 3 & $\mathrm{H}$ & 6 & 26.8 & 26.9 & 194.0 & 5 & 0.708514 & 0.000013 \\
\hline 4 & $\mathrm{H}$ & 3 & 31.8 & 31.9 & 180.8 & 0.9 & 0.708467 & 0.000019 \\
\hline 4 & $\mathrm{H}$ & 5 & 34.8 & 34.9 & 182.7 & 0.9 & 0.708481 & 0.000008 \\
\hline 5 & $\mathrm{H}$ & 4 & 42.8 & 42.9 & 166.4 & 1.5 & 0.708423 & 0.000008 \\
\hline 5 & $\mathrm{H}$ & 6 & 45.8 & 45.9 & 163.7 & 0.6 & 0.708412 & 0.000009 \\
\hline 6 & $\mathrm{H}$ & 3 & 50.7 & 50.8 & 158.3 & 0.7 & 0.708376 & 0.000010 \\
\hline 6 & $\mathrm{H}$ & 6 & 55.3 & 55.4 & 154.9 & 1.7 & 0.708376 & 0.000012 \\
\hline 7 & $\mathrm{H}$ & 3 & 60.3 & 60.4 & 155.0 & 1.0 & 0.708353 & 0.000012 \\
\hline 7 & $\mathrm{H}$ & 6 & 64.8 & 64.9 & 148.1 & 1.0 & 0.708327 & 0.000010 \\
\hline 8 & $\mathrm{H}$ & 3 & 69.8 & 69.9 & 144.9 & 0.9 & 0.708302 & 0.000013 \\
\hline 8 & $\mathrm{H}$ & 6 & 74.35 & 74.45 & 144.4 & 0.9 & 0.708295 & 0.000012 \\
\hline 9 & $\mathrm{H}$ & 3 & 79.3 & 79.4 & 142.6 & 0.7 & 0.708303 & 0.000009 \\
\hline 9 & $\mathrm{H}$ & 5 & 82.3 & 82.4 & 141.3 & 0.6 & 0.708289 & 0.000008 \\
\hline 10 & $\mathrm{H}$ & 3 & 88.82 & 88.92 & 142.2 & 0.6 & 0.708275 & 0.000009 \\
\hline
\end{tabular}




$\begin{array}{llccccccc}10 & \mathrm{H} & 6 & 93.35 & 93.45 & 142.1 & 0.9 & 0.708333 & 0.000007 \\ 11 & \mathrm{H} & 3 & 98.3 & 98.4 & 142.8 & 0.6 & & \\ 11 & \mathrm{H} & 6 & 102.71 & 102.81 & 140.6 & 0.6 & 0.708310 & 0.000010 \\ 12 & \mathrm{H} & 3 & 107.83 & 107.93 & 139.7 & 0.6 & 0.708325 & 0.000009 \\ 12 & \mathrm{H} & 6 & 112.1 & 112.2 & 139.0 & 0.7 & 0.708317 & 0.000009 \\ 13 & \mathrm{H} & 2 & 115.81 & 115.91 & 138.5 & 0.6 & 0.708318 & 0.000007 \\ 14 & \mathrm{H} & 5 & 127.49 & 127.59 & 135.7 & 0.8 & 0.708347 & 0.000008 \\ 15 & \mathrm{H} & 3 & 134.33 & 134.43 & 132.1 & 0.7 & 0.708356 & 0.000008 \\ 15 & \mathrm{H} & 6 & 138.8 & 138.9 & 133.8 & 1.0 & 0.708327 & 0.000033\end{array}$

340-U1397B-

$\begin{array}{ccccccccc}1 & \mathrm{H} & 3 & 4.4 & 4.5 & 85.7 & 0.4 & 0.709165 & 0.000007 \\ 2 & \mathrm{H} & 3 & 10.82 & 10.92 & & & & \\ 2 & \mathrm{H} & 6 & 15.32 & 15.42 & 86.8 & 1.0 & 0.709138 & 0.000006 \\ 3 & \mathrm{H} & 2 & 19 & 19.1 & 88.3 & 0.4 & 0.709126 & 0.000006 \\ 3 & \mathrm{H} & 5 & 23.36 & 23.46 & 94.5 & 1.9 & 0.709124 & 0.000007 \\ 5 & \mathrm{H} & 2 & 37 & 37.1 & 105.0 & 1.3 & 0.709084 & 0.000008 \\ 5 & \mathrm{H} & 6 & 42.55 & 42.65 & 105.3 & 0.9 & 0.709098 & 0.000006 \\ 6 & \mathrm{H} & 2 & 46.5 & 46.6 & 106.8 & 1.0 & 0.709072 & 0.000007 \\ 6 & \mathrm{H} & 6 & 52.5 & 52.6 & 106.3 & 1.0 & 0.709094 & 0.000008 \\ 9 & \mathrm{H} & 4 & 75.55 & 75.65 & 119.1 & 1.1 & 0.709092 & 0.000008 \\ 23 & \mathrm{X} & 2 & 164.02 & 164.12 & 108.6 & 0.9 & 0.709092 & 0.000009 \\ 23 & \mathrm{X} & 5 & 168.52 & 168.62 & 110.8 & 1.0 & 0.709088 & 0.000007 \\ 24 & \mathrm{X} & 2 & 173.6 & 173.7 & 113.7 & 1.1 & 0.709102 & 0.000006 \\ 25 & \mathrm{X} & 1 & 181.6 & 181.7 & 113.9 & 0.9 & 0.709091 & 0.000008\end{array}$

340-U1398B-

$\begin{array}{ccccccccc}9 & \mathrm{H} & 3 & 62.5 & 62.6 & 60.9 & 0.4 & 0.709017 & 0.000008 \\ 9 & \mathrm{H} & 5 & 65.5 & 65.6 & 58.8 & 0.4 & 0.709044 & 0.000007 \\ 11 & \mathrm{H} & 2 & 76.7 & 76.8 & 57.1 & 0.6 & 0.709030 & 0.000008 \\ 12 & \mathrm{H} & 2 & 85.8 & 85.9 & 55.7 & 0.4 & 0.708993 & 0.000005 \\ 14 & \mathrm{H} & 3 & 100.3 & 100.4 & 57.9 & 0.5 & 0.708947 & 0.000006 \\ 14 & \mathrm{H} & 5 & 103.3 & 103.4 & 58.2 & 0.5 & & \\ 15 & \mathrm{H} & 3 & 109.79 & 109.89 & 60.7 & 0.5 & & \\ 15 & \mathrm{H} & 5 & 112.71 & 112.81 & 61.7 & 0.4 & & \\ 18 & \mathrm{H} & 3 & 130.9 & 131 & 67.9 & 0.4 & & \\ 18 & \mathrm{H} & 6 & 134.97 & 135.07 & & & & \\ 19 & \mathrm{H} & 2 & 138.9 & 139 & 73.4 & 0.4 & & \\ 19 & \mathrm{H} & 3 & 140.4 & 140.5 & 75.2 & 0.6 & & \\ 20 & \mathrm{H} & 2 & 148.36 & 148.46 & 80.2 & 0.6 & 0.708634 & 0.000018 \\ 20 & \mathrm{H} & 6 & 154.24 & 154.34 & 84.9 & 0.4 & 0.708655 & 0.000017 \\ 22 & \mathrm{H} & 2 & 160.22 & 160.32 & 94.0 & 0.5 & 0.708593 & 0.000017 \\ 22 & \mathrm{H} & 4 & 163.15 & 163.25 & 98.6 & 0.5 & 0.708564 & 0.000031 \\ 23 & \mathrm{H} & 1 & 166.3 & 166.4 & 99.8 & 0.6 & 0.708641 & 0.000021 \\ 27 & \mathrm{X} & 1 & 187.47 & 187.57 & & & & \\ 34 & \mathrm{X} & 1 & 254.08 & 254.19 & 161.8 & 1.1 & 0.7085584 & 0.000030\end{array}$

340-U1399B-

$\begin{array}{ccccccccc}1 & \mathrm{H} & 2 & 2.9 & 3 & 99.4 & 0.9 & 0.709161 & 0.000007 \\ 2 & \mathrm{H} & 3 & 10.1 & 10.2 & 86.1 & 1.2 & 0.709153 & 0.000008\end{array}$




$\begin{array}{ccccccccc}3 & \mathrm{H} & 3 & 19.62 & 19.72 & 85.2 & 1.0 & 0.709123 & 0.000007 \\ 3 & \mathrm{H} & 5 & 22.6 & 22.7 & & & & \\ 4 & \mathrm{H} & 2 & 27.6 & 27.7 & 82.1 & 1.0 & 0.709098 & 0.000009 \\ 4 & \mathrm{H} & 4 & 30.6 & 30.7 & 78.9 & 0.9 & 0.709068 & 0.000006 \\ 5 & \mathrm{H} & 3 & 38.6 & 38.7 & 77.2 & 0.9 & 0.709064 & 0.000008 \\ 5 & \mathrm{H} & 5 & 41.6 & 41.7 & 75.4 & 0.8 & 0.709060 & 0.000008 \\ 6 & \mathrm{H} & 2 & 46.5 & 46.6 & 72.1 & 1.1 & 0.709055 & 0.000007 \\ 6 & \mathrm{H} & 4 & 49.45 & 49.55 & 72.0 & 0.8 & 0.709086 & 0.000008 \\ 8 & \mathrm{H} & 1 & 64.12 & 64.22 & 68.3 & 0.8 & 0.709070 & 0.000009 \\ 8 & \mathrm{H} & 3 & 67.07 & 67.17 & 66.6 & 0.8 & 0.709081 & 0.000007 \\ 9 & \mathrm{H} & 3 & 76.32 & 76.42 & 63.2 & 0.8 & 0.709068 & 0.000010 \\ 12 & \mathrm{H} & 1 & 95.72 & 95.82 & 66.0 & 0.8 & 0.709041 & 0.000009 \\ 13 & \mathrm{H} & 3 & 107.1 & 107.2 & 62.4 & 0.9 & 0.709012 & 0.000007 \\ 15 & \mathrm{H} & 5 & 122.13 & 122.24 & 60.6 & 0.9 & 0.709000 & 0.000008 \\ 18 & \mathrm{H} & 2 & 131.83 & 131.93 & 61.1 & 0.8 & 0.708984 & 0.000006 \\ 24 & \mathrm{H} & 1 & 160.7 & 160.8 & 62.9 & 0.9 & 0.708944 & 0.000010 \\ 25 & \mathrm{H} & 1 & 167.8 & 167.9 & 61.6 & 0.8 & 0.708985 & 0.000010\end{array}$

340-U1400B-

$\begin{array}{ccccccccc}7 & \mathrm{H} & 4 & 31.24 & 31.34 & 87.7 & 0.9 & 0.709230 & 0.000008 \\ 8 & \mathrm{H} & 5 & 42.4 & 42.5 & 87.5 & 0.9 & 0.709200 & 0.000041 \\ 9 & \mathrm{H} & 1 & 45.9 & 46 & 88.5 & 0.9 & 0.709193 & 0.000029 \\ 10 & \mathrm{H} & 3 & 52.91 & 53.01 & 90.9 & 1.0 & 0.709175 & 0.000008 \\ 10 & \mathrm{H} & 6 & 57.42 & 57.52 & 93.5 & 1.0 & 0.709143 & 0.000001 \\ 11 & \mathrm{H} & 4 & 63.92 & 64.02 & 93.3 & 0.8 & 0.709139 & 0.000021 \\ 12 & \mathrm{H} & 2 & 70.08 & 70.18 & 92.8 & 0.8 & 0.709155 & 0.000011 \\ 13 & \mathrm{H} & 5 & 81.4 & 81.5 & 98.4 & 0.8 & 0.709137 & 0.000010 \\ 14 & \mathrm{H} & 3 & 87.85 & 87.95 & 96.6 & 0.9 & & \\ 15 & \mathrm{H} & 4 & 98.8 & 98.9 & 98.0 & 1.1 & 0.709087 & 0.000011 \\ 17 & \mathrm{H} & 4 & 111.53 & 111.63 & 100.1 & 0.9 & 0.709049 & 0.000012 \\ 18 & \mathrm{H} & 4 & 121 & 121.1 & 101.5 & 0.9 & 0.709039 & 0.000009 \\ 19 & \mathrm{H} & 2 & 127.52 & 127.62 & 103.4 & 0.8 & 0.709030 & 0.000011 \\ 20 & \mathrm{H} & 3 & 133.21 & 133.31 & 101.7 & 1.0 & 0.709063 & 0.000012 \\ 21 & \mathrm{H} & 5 & 143.82 & 143.92 & 105.3 & 0.8 & 0.709042 & 0.000006 \\ 22 & \mathrm{H} & 4 & 151.83 & 151.93 & 104.3 & 0.9 & 0.709004 & 0.000013 \\ 23 & \mathrm{H} & 4 & 161.35 & 161.45 & 124.1 & 1.2 & 0.709030 & 0.000008 \\ 24 & \mathrm{H} & 4 & 170.88 & 170.98 & 105.4 & 1.0 & 0.709027 & 0.000011 \\ 25 & \mathrm{H} & 4 & 180.34 & 180.44 & 103.2 & 0.9 & & \\ 26 & \mathrm{H} & 4 & 189.78 & 189.88 & 103.3 & 1.1 & & \\ 27 & \mathrm{H} & 5 & 200.79 & 200.89 & 104.1 & 0.9 & & \\ 28 & \mathrm{H} & 3 & 207.3 & 207.4 & 103.9 & 1.0 & & \end{array}$

340-U1400C-

$\begin{array}{lllllll}27 & \mathrm{X} & 4 & 231.2 & 231.3 & 101.0 & 0.8\end{array}$ 


\begin{tabular}{ccccccccc}
29 & $\mathrm{X}$ & 2 & 247.4 & 247.5 & 104.5 & 0.9 & & \\
30 & $\mathrm{X}$ & 2 & 257 & 257.1 & 104.4 & 0.8 & & \\
31 & $\mathrm{X}$ & 3 & 268.1 & 268.2 & 108.6 & 1.0 & 0.708986 & 0.000014 \\
32 & $\mathrm{X}$ & 2 & 276.2 & 276.3 & 111.8 & 1.1 & 0.709004 & 0.000027 \\
33 & $\mathrm{X}$ & 2 & 285.8 & 285.9 & 111.4 & 1.0 & 0.708987 & 0.000013 \\
35 & $\mathrm{X}$ & 4 & 298.4 & 298.5 & 112.4 & 1.1 & 0.708948 & 0.000008 \\
36 & $\mathrm{X}$ & 3 & 306.5 & 306.6 & 113.9 & 1.0 & 0.708915 & 0.000013 \\
37 & $\mathrm{X}$ & 1 & 313.12 & 313.22 & 116.0 & 0.9 & 0.708937 & 0.000015 \\
38 & $\mathrm{X}$ & 5 & 328.3 & 328.4 & 113.1 & 1.2 & & \\
39 & $\mathrm{X}$ & 5 & 337.71 & 337.81 & 116.2 & 1.2 & 0.708937 & 0.000014 \\
40 & $\mathrm{X}$ & 1 & 341.5 & 341.6 & 113.7 & 1.1 & 0.708916 & 0.000015 \\
41 & $\mathrm{X}$ & 1 & 351.1 & 351.2 & 114.5 & 0.9 & 0.708938 & 0.000013 \\
42 & $\mathrm{X}$ & 2 & 362.2 & 362.3 & 114.3 & 1.5 & 0.708920 & 0.000013 \\
44 & $\mathrm{X}$ & 1 & 379.75 & 379.85 & 115.0 & 1.0 & 0.708900 & 0.000014 \\
45 & $\mathrm{X}$ & 3 & 392.45 & 392.55 & 113.6 & 0.9 & 0.708829 & 0.000012 \\
49 & $\mathrm{X}$ & 1 & 427.48 & 427.58 & 131.0 & 1.3 & 0.708677 & 0.000014 \\
\hline
\end{tabular}


Table A2. Sr isotope composition of solid phase samples from Site U1396.

Sr (ppm)

Top Depth

Sample

Modern Sea

Water

$1 \mathrm{H} 3$

$2 \mathrm{H} 3$

$2 \mathrm{H} 6$

$3 \mathrm{H} 3$

$3 \mathrm{H} 6$

$4 \mathrm{H} 3$

$4 \mathrm{H} 5$

$5 \mathrm{H} 4$

$5 \mathrm{H} 6$

$6 \mathrm{H} 3$

6 H 6

7 H 3

7H 6

$8 \mathrm{H} 3$

8 H 6

9 H 3

$9 \mathrm{H} 5$

$10 \mathrm{H} 3$

10 H 6

$11 \mathrm{H} 3$

11 H 6

$12 \mathrm{H} 3$

12 H 6

$13 \mathrm{H} 2$

$14 \mathrm{H} 5$

$15 \mathrm{H} 3$

15 H 6 (cm)

0

440

1280

1730

2220

2680

3180

3480

4280

4580

5070

5530

6030

6480

6980

7435

7930

8230

8882

9335

9830

10271

10783

11210

11581

12749

13433

13880
Age Ma 0

0.3

0.78

0.99

1.2

1.5

1.77

1.86

2.15

2.25

2.5

2.56

2.7

2.8

3

3.11

3.27

3.33

3.5

3.58

3.7

3.8

3.9

4

4.05

4.18

4.4

4.48
Non-

Carbonate \pm Carobnate \pm Carbonate

1801

803

709

958

858

765

915

1001

710

735

779

487

869

840

1024

996

625

782

519

471

413

410

610

765

524

134

124

180

0.708868

0.709025

0.709099

0.709069

0.708997

127

168

108

0

0.709053

112

0.708995

125

0.708970

0.708877

113

0.709041

150

172

$19 \quad 0.709046$

$24 \quad 102$

12

0.709051

0.709042

0.709022

0.709019

0.709021

$9 \quad 0.709025$

$28 \quad 0.709020$

0.709020

0.709000

7

0.709030

0.709010

0.709020

0.709010 
${ }^{6} \mathrm{Sr}$

Non-

Carbonate

0.707372

0.707296

0.707055

0.707380

0.705320

0.705178 
Table A3. Sr isotope composition and concentrations of bulk digests.

\section{Bottom}

Top Depth Depth (CSF- Corrected

\begin{tabular}{|c|c|c|c|c|c|c|c|c|}
\hline Sample ID & Core & Type & Section & (CSF-A) & A) & ${ }^{87 / 86} \mathrm{Sr}$ & \pm & Sr (ppm) ${ }^{1}$ \\
\hline \multicolumn{9}{|l|}{ 340-1395- } \\
\hline McM313_02 & 1 & $\mathrm{H}$ & 3 & 4.4 & 4.5 & 0.707997 & 0.000007 & 2272 \\
\hline МсM313 03 & 6 & $\mathrm{H}$ & 4 & 49.72 & 49.82 & 0.708198 & 0.000007 & 1772 \\
\hline McM313_04 & 13 & $\mathrm{H}$ & 4 & 112.02 & 112.12 & 0.708251 & 0.000011 & 2042 \\
\hline МсM313 05 & 14 & $\mathrm{H}$ & 3 & 117.3 & 117.4 & 0.707282 & 0.000007 & 547 \\
\hline McM313_12 & 14 & $\mathrm{H}$ & 3 & 117.3 & 117.4 & 0.707159 & 0.000009 & 555 \\
\hline МсM313 06 & 24 & $\mathrm{X}$ & 1 & 185.5 & 185.6 & 0.708299 & 0.000011 & 2533 \\
\hline McM313_07 & 25 & $X$ & 1 & 195.1 & 195.2 & 0.707982 & 0.000008 & 2267 \\
\hline \multicolumn{9}{|l|}{ 340-1397- } \\
\hline McM313_19 & 1 & $\mathrm{H}$ & 3 & 4.4 & 4.5 & 0.707749 & 0.000009 & 715 \\
\hline McM313_20 & 2 & $\mathrm{H}$ & 6 & 15.32 & 15.42 & 0.707553 & 0.000010 & 605 \\
\hline McM313_23 & 2 & $\mathrm{H}$ & 6 & 15.32 & 15.42 & 0.707521 & 0.000006 & 603 \\
\hline McM313_24 & 6 & $\mathrm{H}$ & 2 & 46.5 & 46.6 & 0.707273 & 0.000012 & 460 \\
\hline McM313_25 & 6 & $\mathrm{H}$ & 6 & 52.5 & 52.6 & 0.708124 & 0.000010 & 865 \\
\hline McM313_26 & 24 & $\mathrm{X}$ & 2 & 173.6 & 173.7 & 0.708110 & 0.000008 & 961 \\
\hline McM313_27 & 25 & $X$ & 1 & 181.6 & 181.7 & 0.708170 & 0.000008 & 1204 \\
\hline \multicolumn{9}{|l|}{ 340-1398- } \\
\hline McM313_28 & 9 & $\mathrm{H}$ & 3 & 62.5 & 62.6 & 0.708736 & 0.000009 & 446 \\
\hline McM313_29 & 9 & $\mathrm{H}$ & 5 & 65.5 & 65.6 & 0.708009 & 0.000010 & 418 \\
\hline МсM313 30 & 20 & $\mathrm{H}$ & 6 & 154.24 & 154.34 & 0.708373 & 0.000009 & 891 \\
\hline McM313_31 & 22 & $\mathrm{H}$ & 4 & 163.15 & 136.25 & 0.708338 & 0.000011 & 320 \\
\hline МсM313 34 & 22 & $\mathrm{H}$ & 4 & 163.15 & 136.25 & 0.708278 & 0.000007 & 319 \\
\hline McM313_35 & 34 & $\mathrm{X}$ & 1 & 254.08 & 254.19 & 0.708240 & 0.000008 & 713 \\
\hline \multicolumn{9}{|l|}{ 340-1399B- } \\
\hline McM313 36 & 1 & $\mathrm{H}$ & 2 & 2.9 & 3 & 0.707091 & 0.000005 & 275 \\
\hline МсM313 37 & 2 & $\mathrm{H}$ & 2 & 10.1 & 10.2 & 0.708917 & 0.000006 & 723 \\
\hline МсM313 38 & 6 & $\mathrm{H}$ & 2 & 46.5 & 46.6 & 0.708422 & 0.000009 & 563 \\
\hline МсM313 39 & 6 & $\mathrm{H}$ & 4 & 49.45 & 49.55 & 0.708466 & 0.000008 & 976 \\
\hline McM313_52 & 6 & $\mathrm{H}$ & 4 & 49.45 & 49.55 & 0.708099 & 0.000012 & 977 \\
\hline МсM313 40 & 18 & $\mathrm{H}$ & 2 & 131.83 & 131.93 & 0.707584 & 0.000007 & 550 \\
\hline МсM313 41 & 24 & $\mathrm{H}$ & 1 & 160.7 & 160.8 & 0.707875 & 0.000006 & 561 \\
\hline McM313 42 & 25 & $\mathrm{H}$ & 1 & 167.8 & 167.9 & 0.708690 & 0.000009 & 844 \\
\hline \multicolumn{9}{|l|}{ 340-1400B- } \\
\hline МсM313 45 & 7 & $\mathrm{H}$ & 4 & 31.24 & 31.34 & 0.708060 & 0.000009 & 1049 \\
\hline McM313_46 & 8 & $\mathrm{H}$ & 5 & 42.4 & 42.5 & 0.708140 & 0.000009 & 785 \\
\hline McM313_47 & 27 & $\mathrm{H}$ & 5 & 200.79 & 200.89 & 0.707315 & 0.000006 & 402 \\
\hline МсM313 48 & 28 & $\mathrm{H}$ & 3 & 207.3 & 207.4 & 0.707799 & 0.000008 & 428 \\
\hline \multicolumn{9}{|l|}{ 340-1400C- } \\
\hline МсM313 49 & 33 & $\mathrm{X}$ & 2 & 285.8 & 285.9 & 0.707942 & 0.000014 & 977 \\
\hline McM313_50 & 41 & $X$ & 1 & 351.1 & 351.2 & 0.708491 & 0.000008 & 676 \\
\hline McM313_51 & 49 & $\mathrm{X}$ & 1 & 427.48 & 427.58 & 0.708325 & 0.000007 & 514 \\
\hline
\end{tabular}

${ }^{1}$ Sr concentration data from Murray et al. (2016) 


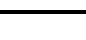

$\pm$

8
10
10
3
3
10
14

8

3

4

2

8

9

3
3
8
2
2
7

2

8

3

9

9

3

9

7

7

2

2

8

7

5 



\author{
Sample ID Descriptio \\ Leg \\ Site \\ McM313 1: PACS-2 \\ McM313_3: RR9702A-42MC \\ McM313_2: RR9702A-42MC \\ McM313 33 PACS-2 \\ McM313 1I RR9702A-42MC \\ MCM313 22 PACS-2 \\ McM313 43 RR9702A-42MC \\ McM313 44 PACS-2
}


$0.7071927 \quad 0.00000608$ $0.7065362 \quad 0.00000928$ $0.7064273 \quad 0.0000173$

$0.70715 \quad 0.0000104$ $0.7064023 \quad 0.00000701$ $0.7073012 \quad 0.00000715$ $0.7066031 \quad 0.00000879$ $0.7071852 \quad 0.0000119$ 